Article

\title{
Parts and Wholes: The Role of Animals in the Performance of Dolenjska Hallstatt Funerary Rites
}

\author{
Adrienne C. Frie \\ Department of Anthropology, Global Religions, and Cultures, University of Wisconsin Oshkosh, \\ Oshkosh, WI 54901, USA; friea@uwosh.edu
}

Received: 18 March 2020; Accepted: 21 April 2020; Published: 26 April 2020

\begin{abstract}
There is a rich iconographic tradition demonstrating the importance of animals in ritual in the Dolenjska Hallstatt archaeological culture of Early Iron Age Slovenia (800-300 вСЕ). However, the role of animals in mortuary practice is not well represented iconographically, though faunal remains in graves indicate that their inclusion was an integral part of funerary performance. Here, animal bones from burials are compared to images of animal sacrifice, focusing on the ritual distinctions between the deposition of whole animal bodies versus animal parts. It is proposed that human-animal relationships were a key component of funerary animal sacrifice in these multispecies communities. The deposition of whole horses may have been due to a personal relationship with the deceased human. In turn, the sacrifice of an animal and division of its parts may have been essential for the management of group ties with the loss of a community member. Particular elements such as teeth, horns, and claws may have served as amulets-perhaps indicating that these were personal items that had to be placed in the grave with the deceased or that the deceased needed continued protection or other symbolic aid.
\end{abstract}

Keywords: human-animal relations; animal sacrifice; zooarchaeology; multispecies communities; situla art; mortuary archaeology; funerary ritual; Early Iron Age; Hallstatt culture; Slovenia

\section{Introduction}

Mortuary rituals are key sites for mediating grief and providing appropriate care and respect for the decedent, but also for negotiating the reorganization of the community in the absence of the newly deceased individual (Boyd 2014, p. 194; Fahlander and Oestigaard 2008, p. 10). The role of animals in rituals related to these two facets of mortuary practice are presented here-first, the role of ritual animals related to the identity of the deceased human individual and, second, the role of animals in rituals that may have been important to negotiations of community following the traumatic event of death. I present evidence for animal sacrifice during funerary rituals using faunal remains from graves and imagery from Early Iron Age Slovenia. The results demonstrate that there are important distinctions between the deposition of whole animal bodies versus animal parts. Finds of fully articulated animal bodies in mortuary contexts have long drawn attention, as they more clearly indicate animal sacrifice. Finds of animal parts are have received less attention and are often briefly characterized as food offerings, feasting refuse, or a pars pro toto offering. All of these are plausible and indeed intriguing possibilities that deserve to be more explicitly theorized. This article explores how the different forms of animal remains in graves indicate variability in funerary ritual and the complex ways in which multispecies communities were involved in the management of death.

Funerary practices maintained a distinct place in the broader sphere of ritual activities because the death and burial of a community member and the practices and performances associated with such an event were not everyday occurrences. Death is damaging at multiple social scales, from the grief of those closest to the decedent to the loss experienced by the community and the attendant political, 
economic, and other social repercussions. Funerals may be essential to manage the upheaval and uncertainty that follows death, from reinforcing family relationships and restructuring social roles and alliances to facilitating group cohesion (Fahlander and Oestigaard 2008; Nilsson Stutz and Tarlow 2013; Parker Pearson 1999; Tarlow 1999).

In the Early Iron Age Dolenjska Hallstatt culture (800-300 все), there is a rich iconographic tradition attesting to the central importance of animals in ritual performances including hunting, sacrifice, and feasting (Eibner 1981; Frie 2016, 2018a, 2018b, 2019; Križ 2012; Turk 2005). What is not clear is the role of animals in mortuary ritual, though the presence of faunal remains in graves of the period indicates that they were an integral part of certain funerary performances (Dular 2007; Kmet'ová 2013a, 2013b, 2018; Kmet'ová and Stegmann-Rajtár 2014; Škvor Jernejčič and Toškan 2018). There was something about these animals, in particular their relationship with local people, which led to their sacrifice and inclusion in graves. While animal sacrifice is commonly interpreted as a demonstration of status, or evidence of conspicuous consumption or grave gifts, here, I draw attention to the significance of human-animal relationships in multispecies communities as a key component of animal sacrifice (Hamilakis and Overton 2013; Pilaar Birch 2018; Watts 2013).

The results of this study demonstrate that most animals deposited in graves were domestic animals, and the vast majority were horses. It is proposed that the sacrifice of horses was due to a personal relationship with the deceased, likely their rider. Whole horse bodies associated with graves may reflect the unique and close relationship between rider and horse, which may have been perceived to extend into the afterlife, where they travelled in death as they had travelled in life. In turn, the sacrifice of an animal during the funerary ritual and the partition of its body may have been significant to the larger community. The act of sacrifice, where the deceased participated in the apportioning of animal parts to strengthen the community whole, marked their membership in the group, but also may have begun the process whereby social ties were reconfigured with one less living member. Finally, certain animal parts, such as teeth, horns, and claws, may have served as amulets with protective qualities, and these offer intriguing insight into the curation and manipulation of animal remains.

\section{The Dolenjska Hallstatt Culture}

The Dolenjska Hallstatt culture dates from approximately 800 to 300 все in modern southeastern Slovenia. This archaeological culture is part of the larger Eastern Hallstatt cultural complex. This period is characterized by the adoption of iron production and settlement at hillforts. These settlements were surrounded by inhumations in burial mounds referred to as tumuli, where social hierarchies were marked by the distribution of grave goods, burial location within the mound, and grave construction (Dular 2003; Dular and Hvala 2007; Gabrovec 1976; 1999, pp. 150-70). While in other parts of the Hallstatt world these monumental tumuli are considered the burial locations of princes or chieftains and their elite lineages (Arnold 2001, 2011; Burmeister 2000; Frey 1991; Kimmig 1991), the social distinctions evident in Dolenjska Hallstatt mounds are less extreme, and it is believed that these were family or clan burial places (Dular and Hvala 2007, pp. 126, 247; Gabrovec 1966, pp. 14, 43; Tecco Hvala 2012, pp. 41, 80).

The Early Iron Age was also marked by a significant increase in figural art. Southeastern Europe was a center for the circulation of recurring sets of motifs, styles, and artifacts elaborated with imagery (Eibner 1981; Frey 2011; Lucke and Frey 1962). Situla art is a style centered in the northern Adriatic and is particularly important archaeologically because the narrative representations provide insight into Early Iron Age life (Figure 1). This is a toreutic figural art that appears on the eponymous situlae, or bronze buckets used for mixing and serving alcohol; other bronze vessels; belt plates; and various sheet-bronze artifacts (Eibner 1981; Križ 2012; Lucke and Frey 1962; Turk 2005). It has been proposed that these items were used in elite activities but also depict them due to their depositional contexts and the activities represented (Eibner 1981; Križ 2012, pp. 55-59; Kromer 1980, pp. 225-40). Situla art scenes depict processions, feasting, boxing matches, chariot races, musicians and dancers, sexual activity, hunting, and plowing (Eibner 1981; Frey 2011; Križ 2012, pp. 58-59). 

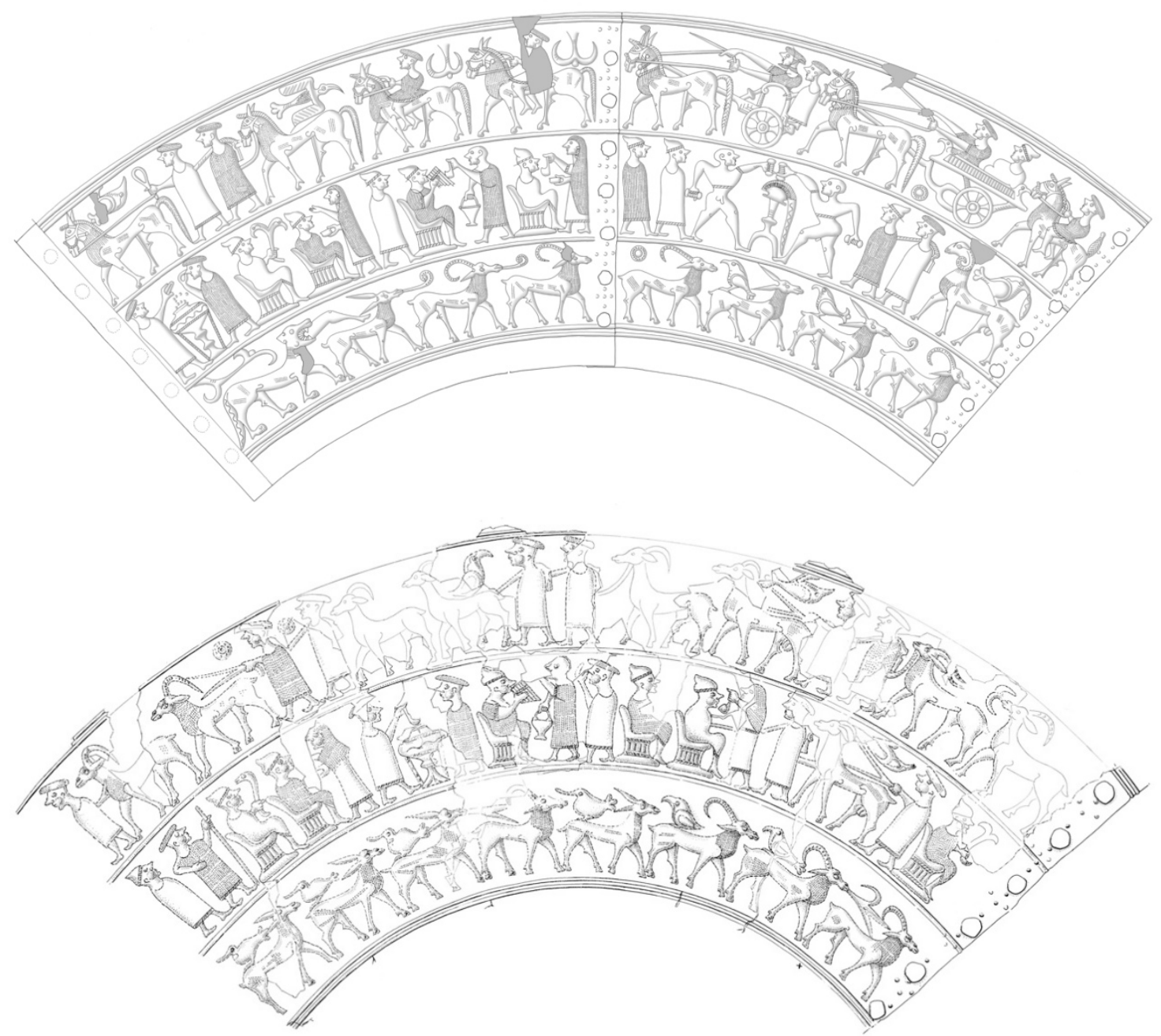

Figure 1. Situlae depicting scenes of animal sacrifice. Top: Vače situla from Grave 1881/1 at Vače—Reber; Narodni muzej Slovenije inventory number P 581 (Laharnar and Turk 2018, 99 Figure 110; (C) National Museum of Slovenia, drawing by Ida Murgelj). Bottom: Situla from Magdalenska gora-Preloge Grave 13/55; Naturhistorisches Museum Wien inventory number 27550 (Tecco Hvala et al. 2004, Insert 5; reproduced by permission of Sneža Tecco Hvala).

There has been significant work done in Slovenia to systematically analyze the artifacts and records from antiquarian excavations to reconstruct the original grave contexts, which has allowed for a more complete understanding of sites excavated prior to the development of modern archaeological methods (Gabrovec 2006; Gabrovec and Teržan 2010; Hencken 1978; Tecco Hvala et al. 2004; Tecco Hvala 2012; Wells 1981). While the reconstruction of certain contexts remains problematic due to the haphazard nature of antiquarian excavations (Božič 2009; Tecco Hvala 2012, p. 28), many of these excavations were far more extensive than those from more recent periods and account for significant archaeological material. Thus, the inclusion of material from older excavations often provides the best opportunity to study large-scale patterns in mortuary practices, especially with reference to rituals involving animals, as these sites also have the most numerous preserved faunal remains (Bökönyi 1968; Dular 2007; Gabrovec 2006; Gabrovec and Teržan 2010; Tecco Hvala 2012, pp. 28, 386). Increasingly poor preservation of osseous materials has been noted in the last century, which may relate to more intensive agricultural production since the Industrial Revolution due to the machinery used and pesticides that have increased soil acidity (Križ 1997, p. 27).

Zooarchaeological analyses of material from the Slovenian Iron Age, particularly from Dolenjska Hallstatt culture sites, have been limited (Bartosiewicz 1999b, p. 315; Dular and Hvala 2007, pp. 28-34). 
There is only a recent tradition of zooarchaeology in Slovenia: earlier studies were undertaken by foreign specialists (Bartosiewicz 1999b), and while new work on Iron Age remains has been undertaken by Borut Toškan, the focus has been on more recently excavated sites (Škvor Jernejčič and Toškan 2018; Toškan 2017a). As previously noted, the soil in Dolenjska is highly acidic, so preservation of bone is poor to non-existent in many areas (Bartosiewicz 1996, p. 30). The haphazard recovery and sporadic analysis of most Dolenjska Hallstatt faunal remains, along with their overall poor preservation, has led to a general dismissal of zooarchaeological evidence from this period. Despite these issues, larger patterns are visible in the reassessment of this material. This reinterpretation of previously reported material is also intended to provide an example for those dealing with data from older or unsystematic excavations.

The faunal dataset from most of these sites does not allow a fine scale analysis of perimortem treatment of animals. However, it is clear from the preserved remains as well as from excavation reports that there were two main categories of animal deposition in this region-depositions of whole animals, almost exclusively horses, and the deposition of animal parts from various local species. These practices will be contextualized with a comparison to local iconography as well as anthropological research on animal sacrifice.

\section{Faunal Remains in Mortuary Contexts}

Forty-five mortuary sites were surveyed in the course of a larger study assessing Dolenjska Hallstatt human-animal relations using animal imagery and zooarchaeological remains (Frie 2017). Zooarchaeological remains were identified from published reports and unpublished excavation notes at 15 mortuary sites in this study, or one-third of the mortuary sample. However, this is likely an underrepresentation of the frequency of animal deposition in mortuary contexts because, as previously noted, soils in Dolenjska and Bela krajina are very acidic and osseous materials rarely preserve (Bartosiewicz 1996, p. 30). There are 68 mortuary contexts with recorded animal bones; 59 of these are graves, while nine are stray finds (Table A1 in Appendix A).

Zooarchaeological remains are most common in graves from sites near Magdalenska gora, Stična, and Libna. Most of these sites were excavated at least partially in the late 19th and early 20th centuries, which makes it difficult to assess the minimum number of individuals (MNI) for each context (Gabrovec 2006; Gabrovec and Teržan 2010; Guštin 1976; Hencken 1978; Tecco Hvala et al. 2004; Tecco Hvala 2012; Wells 1981). Probable male ${ }^{1}$ graves are most commonly associated with zooarchaeological remains and are more likely to have remains of multiple animals in a grave (Figure 2). There are only eight probable female graves associated with faunal remains, though there are also 17 indeterminate graves with faunal remains that cannot be gendered according to the parameters of this study. The four horse graves contained solely horses, without associated human remains. There are no children's graves with faunal remains.

Horses were by far the most common animals deposited in graves, appearing in 44 graves including the four horse burials (Figure 3). Animal remains that have not been identified are a distant second, while dogs and deer each appear in three graves. Cattle bones appeared in two contexts, only one of which is a grave. However, this grave contained nine astragali (two right and seven left), a left and right calcanei, and a left os centrale. These remains account for at least seven animals, so while the bone remains initially seem relatively modest, Magdalenska gora-Preloge Grave IV/43 represents the largest number of cattle remains associated with a single burial (Bökönyi 1968, pp. 11-12; Hencken 1978, p. 25). Finds of astragali have often been considered gaming pieces or divinatory aids, though the presence of the calcanei and os centrale likely indicate that a left and right hock were placed in the grave with

1 Gender attributions have been determined on the basis of grave goods because osteological analysis has not been undertaken to assess biological sex. "Probable" gender is used to reflect the issues of ascribing gender solely on the basis of grave goods (Arnold 2006; Brumfiel 2006). See (Frie 2017, pp. 76-78) for full details about gender assessment in this study. 
the disarticulated atragali (Bartosiewicz 1999a; Dandoy 2006; De Grossi Mazzorin and Minniti 2013; Wiesner 2013). The grave also contained an entire horse, representing the most significant concentration of animals in a single grave (Bökönyi 1968, pp. 11-12; Hencken 1978, pp. 25-26).

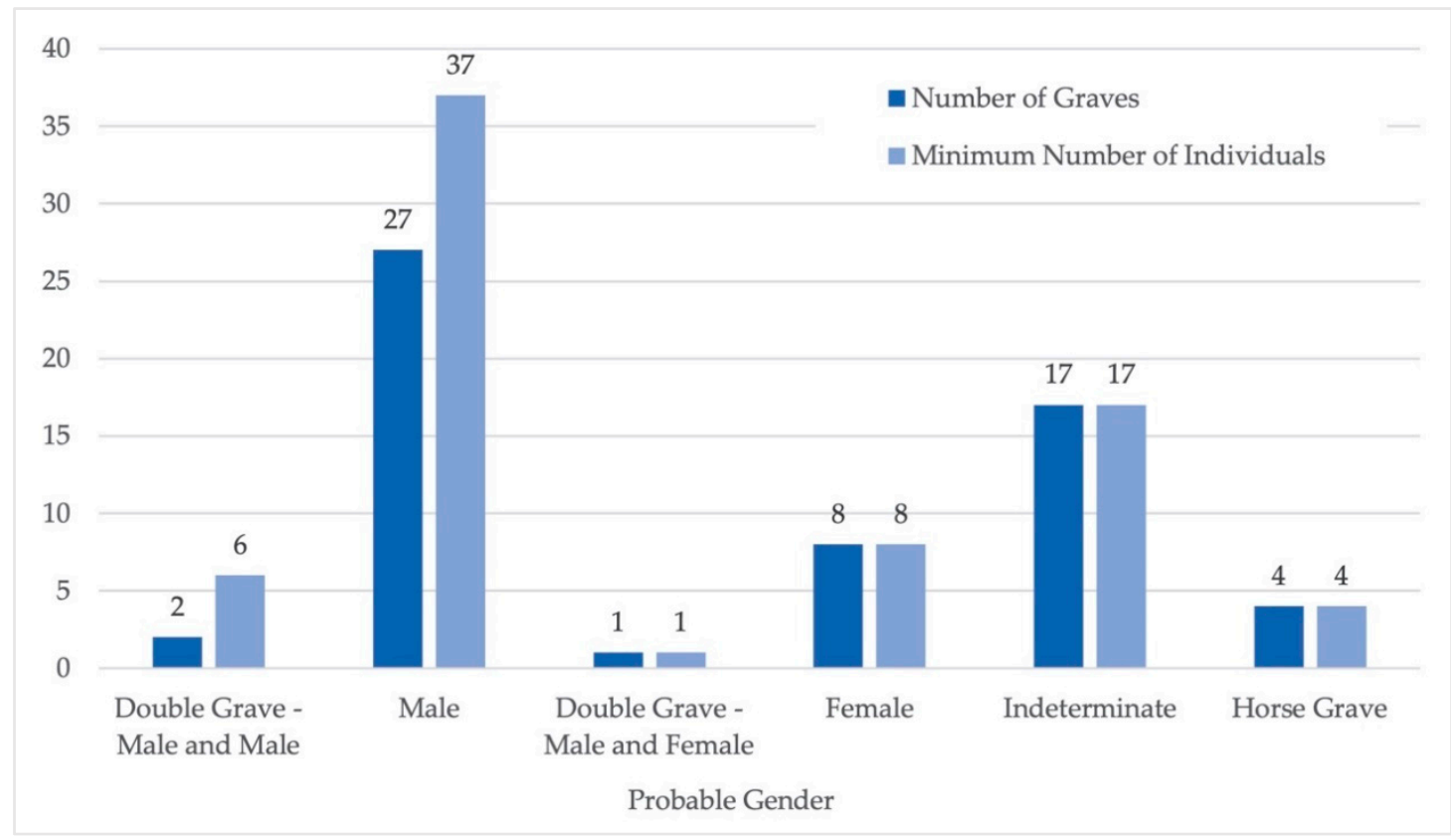

Figure 2. Probable gender of the deceased associated with grave contexts containing faunal remains. Double graves are single graves that contain two individuals.

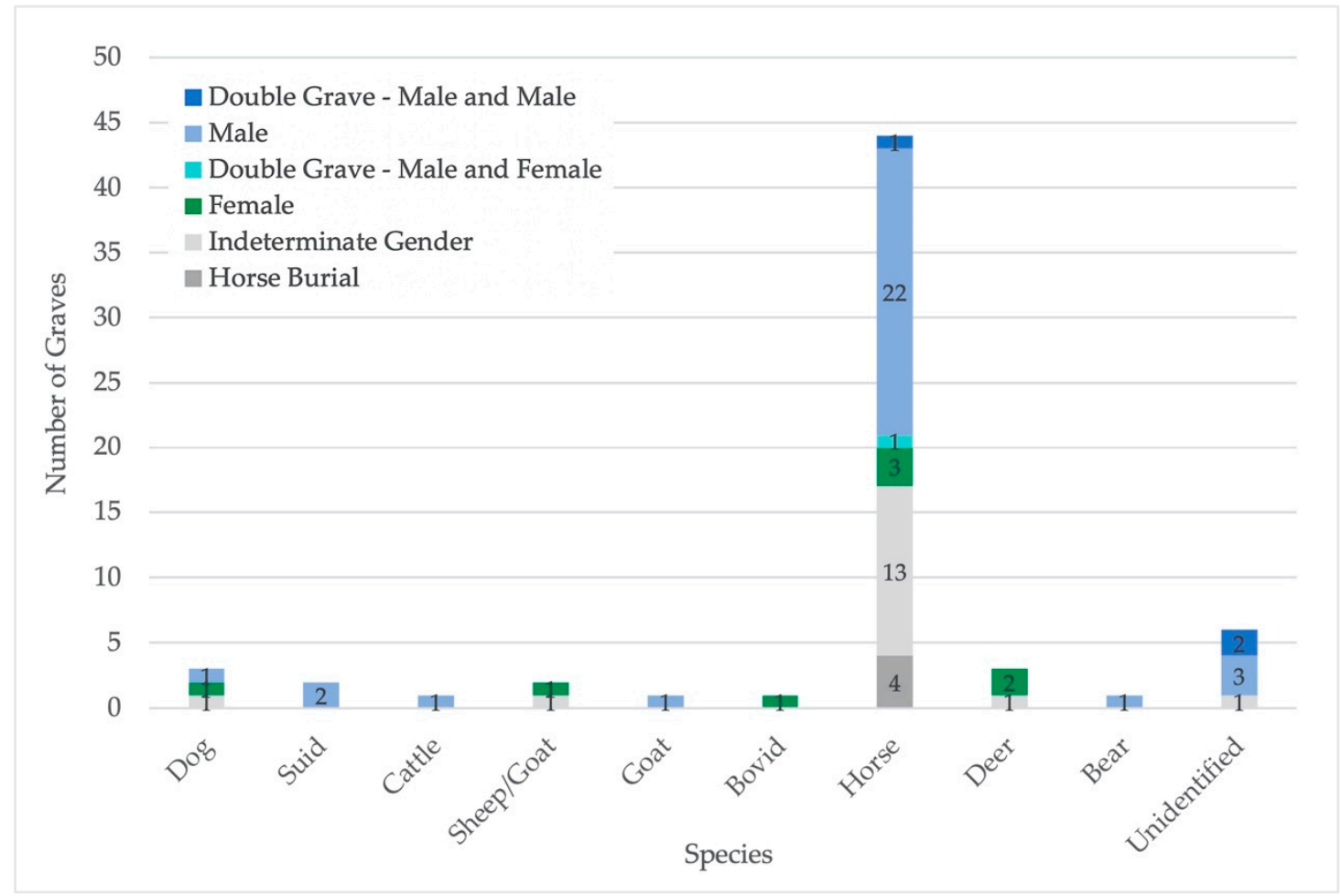

Figure 3. Faunal remains in graves divided by species and probable gender of decedent, does not include stray finds. 
Interestingly, Grave V/11 at Laščik near Magdalenska gora contained the pierced claw of a brown bear (Hencken 1978, p. 32), though bears do not appear in the iconographic record (Frie 2017). Pig remains were identified in Grave 17/6 at Grmada near Molnik as well as possibly in Grave X/52 at Preloge near Magdalenska gora, though species was unidentified for the latter and there are no details about the specific elements found (Bökönyi n.d.; Hencken 1978, p. 75; Škvor Jernejčič 2017, pp. 144-50; Toškan 2017a). It would be notable if these remains were also domestic pig, because these are absent from the iconographic dataset (Frie 2017, p. 124). Overall, the species deposited in graves were not very diverse, and domestic animals dominated the dataset including food animals (pigs, cattle, sheep, goat) and non-food animals (dogs, horses) (Bartosiewicz 1991, p. 199; Bökönyi 1994, p. 202). The only wild animal remains found in graves were the aforementioned bear claw and deer remains from three graves. Boar canines were also found in Dolenjska Hallstatt graves, often pierced for suspension; however, because exact provenience for these finds has not yet been published, they were left out of this study (Frie 2017, p. 255; Teržan forthcoming).

When the different species were assessed according to the probable gender of the deceased individual, additional patterns emerged (Figure 3). Both male and female graves contained a variety of species-males were associated with cattle, goat, suids, dogs, bear, and a large number of horses. Male graves contained faunal remains at triple the rate of female graves, and $80 \%$ of the male graves contained horse remains. The dominance of male graves is not due to greater archaeological visibility; in fact, the broader study identified females at a slightly higher rate than males, and it seems that females were indeed buried with animal remains much less frequently than males (Frie 2017, pp. 105-6). Ungulates dominated the animal remains from female graves-sheep/goat, deer, and an indeterminate bovid were all associated with female graves, and the three female graves with horse remains fit in this category as well. All of these were deposits of partial remains or teeth; thus far, whole animals have not been recovered from female graves. The dog was the only non-ungulate associated with a female grave, though this was solely a tooth, so it otherwise fits the pattern (Tecco Hvala et al. 2004, pp. 152-53). It is difficult to interpret the deposition of animal remains in female graves because it is such a small sample, and many of the details of the finds are unknown due to the limited records from antiquarian excavations. The partial remains may be from food deposits or feasting refuse because several are limbs, while the teeth ${ }^{2}$ may have had some apotropaic or prophylactic function as suggested by previous studies (Pauli 1975; Škvor Jernejčič and Toškan 2018). It is important to note that the animal deposits from female graves did not deviate significantly from those associated with males, except for the clear association of horse sacrifices with male graves. Graves for which gender could not be determined contained dog, sheep/goat, horse, deer, and unidentified remains.

Because there are rarely details about the exact elements present in burials, this project captures the distinctions between burials of the whole animal versus partial remains (Figure 4). Crania, horns, teeth, and claws are distinguished from other partial remains. The only animals buried whole in the sample were 14 horses and a dog. The dog burial was from Grave I/13 at Vir near Podzemelj (Barth 1969, p. 149). The whole horses were all associated with probable male or indeterminate gender burials. Grave XVI/34 from Novo mesto, Kapiteljska njiva has been proposed as the burial of a whole horse associated with a female (Dular 2007, p. 739); however, the excavators only identified teeth and some parts of what were thought to be cranial bones, and the bones have not yet been analyzed (Stipančić 2016a, personal communication).

2 While it is possible that cranial elements or larger parts of animal bodies may have been deposited and solely teeth preserved while the surrounding bone was lost, finds of singular, non-adjacent, and modified teeth indicate that several of these deposits did originally consist of disarticulated teeth. 


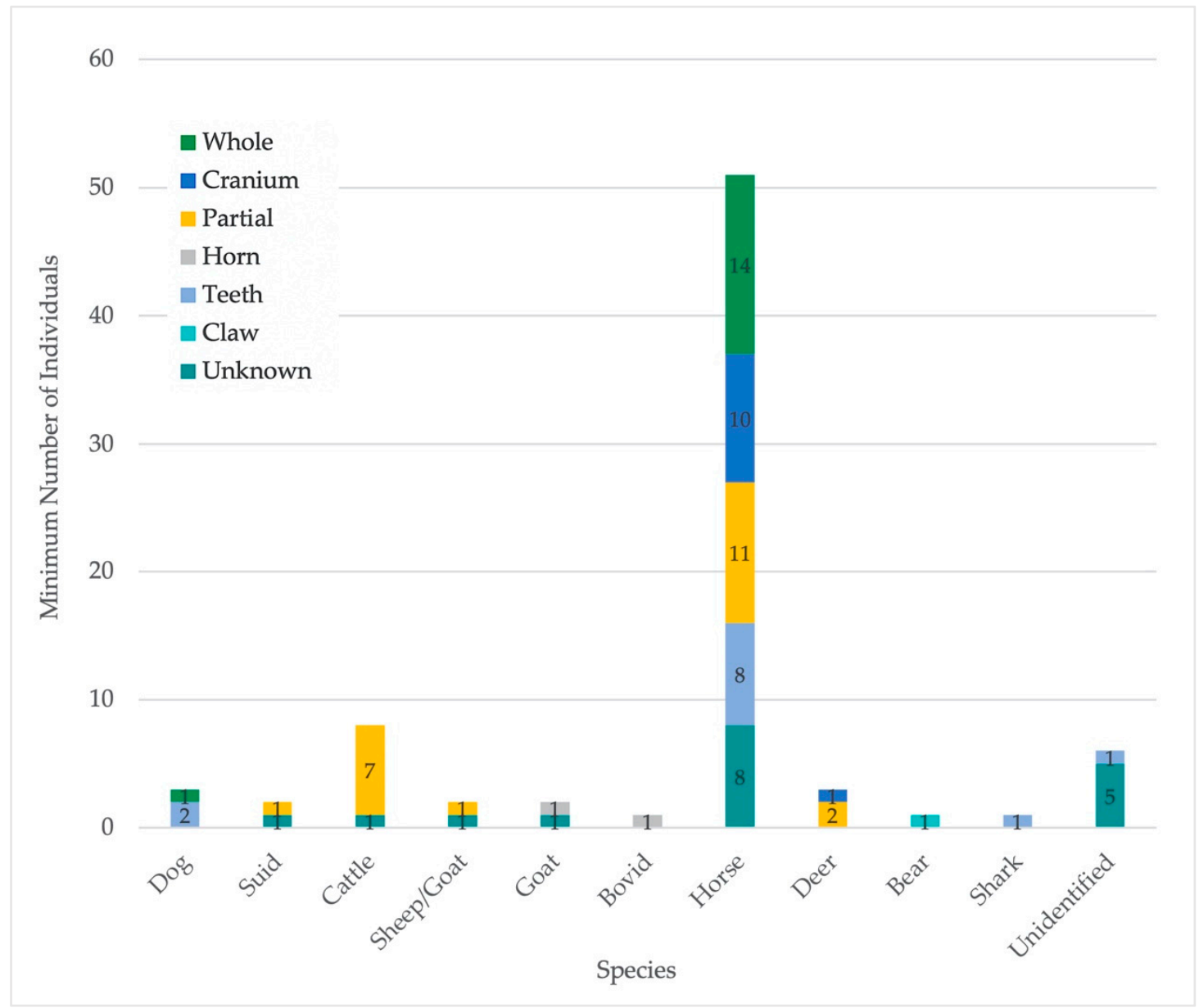

Figure 4. Faunal remains from mortuary contexts divided by the completeness of the remains.

Horses are the only species represented by whole skulls, while deer are the only species represented by cranial fragments. The deer remains from Magdalenska gora, Preloge Grave VII/38 is represented by a cranial fragment from the left side of the head and was deposited with the left tibia of a horse (Bökönyi 1968, p. 14; Hencken 1978, p. 57). Similarly, Grave 31 from the same tumulus also contained a left cranial fragment from a roe deer and the left astragalus of a horse. The concordance between species, side, and part of the body defies coincidence and cannot be attributed to taphonomy. It seems that the deposit of deer left cranial elements and horse left limb elements was meaningful in this context, though whether this was due to a particular funerary practice, conceptions of the animals themselves, a meaningful connection between the human decedents, or another factor, we will likely never know. However, Grave VII/31 dates to the subsequent Late Iron Age (La Tène period) and so is not included in the quantitative analyses here (Bökönyi 1968, p. 14; Hencken 1978, p. 51). These two graves are categorized as indeterminate gender in this study, though they have been considered female graves in other publications (Tecco Hvala 2012, p. 430). The other deer remains are partial remains. Many animals are represented solely by teeth, horses most frequently. The fossilized tooth of a megalodon shark (Carcharocles megalodon) is exceptional as the only fossil in the dataset. This came from Apno near Vače, and the fossil itself probably originated from the area around Moravče near Vače (Leghissa 2015, p. 290; Starè 1955, p. 125).

Very few faunal remains can be dated to the Early Hallstatt period (Figure 5). Five graves containing horses, one of which also contained pig remains, can be dated to the period from 800 to 600 все. These are Brezje pri Trebelnem Grave VI/5; Molnik—Grmada Grave 17/6; Novo mesto-Kapiteljska njiva Tumulus I/Central Grave; Novo mesto-Malenškova gomila/1; and Libna-Špiler Grave I/6 (Guštin 1976, pp. 38, 56-68; Guštin and Teržan 1975, pp. 188-89; Knez 1993, pp. 35, 55; Knez and Škaler 1968, pp. 250-25; 
Križ et al. 2014, pp. 477-78; Kromer 1959, p. 21; Škvor Jernejčič 2017, pp. 144-50; Teržan 2014). Interestingly, four of these five early graves with horses are male graves, and gender could not be determined for the fifth grave. Two of these early graves, Grave VI/5 from Brezje pri Trebelnem and Grave 17/6 from Grmada at Molnik, were cremation graves where the deceased and the horse were both cremated, though in the latter, a small number of domestic pig remains were also identified (Dular and Križ 1990, p. 535; Kromer 1959, p. 21; Škvor Jernejčič 2017, pp. 144-50; Toškan 2017a). These cremation graves show connections to earlier ritual forms. The cremation of humans was the dominant burial form in the preceding Late Bronze Age Urnfield period, though the cremation of horses in these contexts is not well attested. However, the cremated pig remains in Grave 17/6 support this continuity with earlier periods - the Late Bronze Age site of Zadovinek in Dolenjska also contained pig remains, and graves from the Late Bronze Age cemetery at Dvorišče SAZU in Ljubljana frequently contained pig remains (Puš 1971, 1982; Škvor Jernejčič 2014; Toškan 2017b, personal communication).

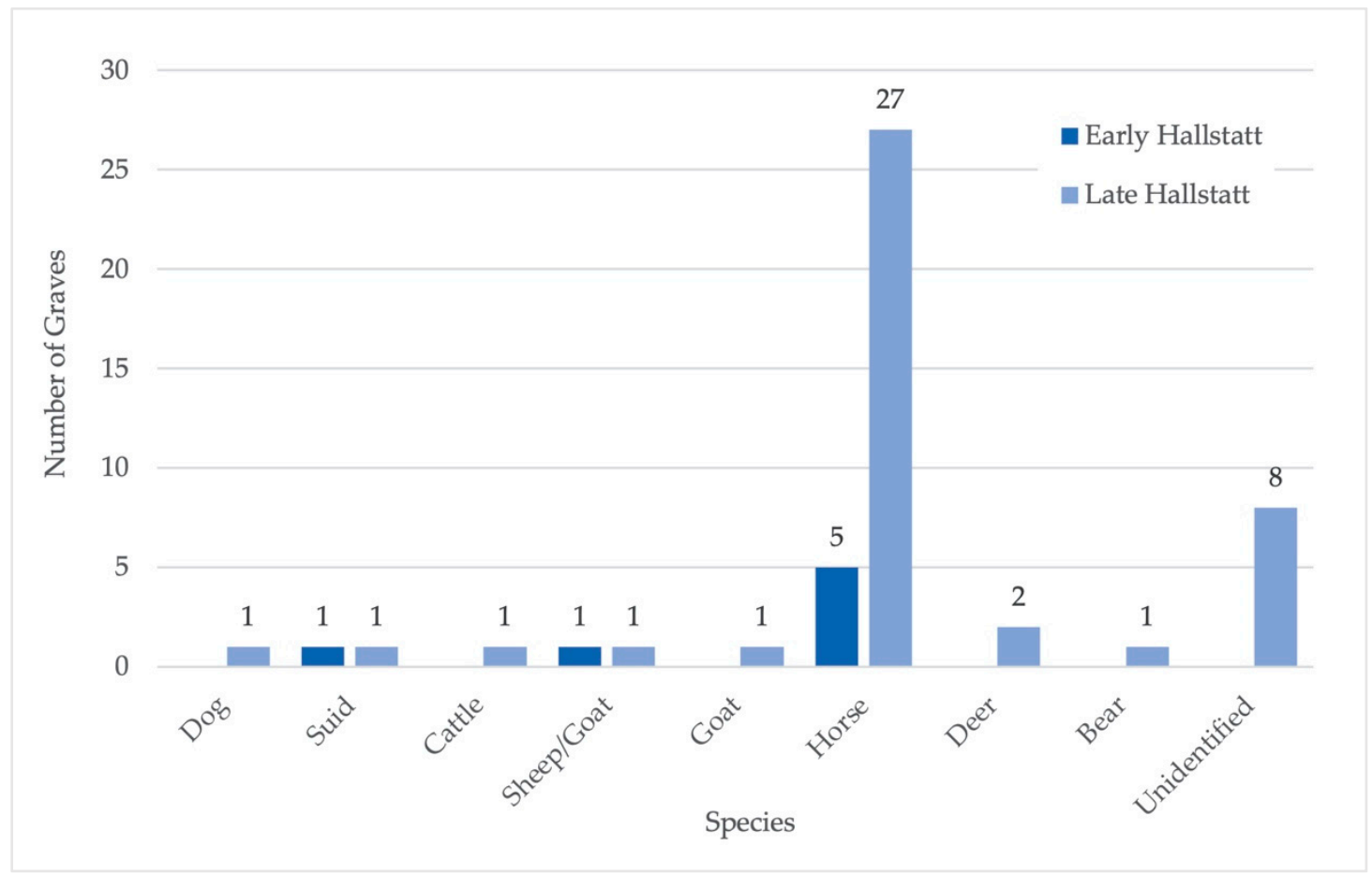

Figure 5. Comparison of zooarchaeological remains dating to the Early Hallstatt (с. 800-600 вСЕ) and Late Hallstatt (600-300 все) periods. Only dateable graves were included.

Zooarchaeological remains show a large increase in the Late Hallstatt period: 43 graves can be dated to the period from 600 to 300 все, including 27 graves containing horses (Dular 2007; Frie 2018a). Notably, all three female graves containing horse remains can be dated to the end of the Late Hallstatt period, in the local Negova Helmets phase (circa 460-300 всE; Hencken 1978, p. 68; Križ et al. 2014, p. 482; Tecco Hvala 2012, p. 346; Wells 1981, p. 66). It seems that, initially, most deposits of animal remains in grave contexts were horses associated with male graves. Over time, the variety of species increased and animal deposition was no longer exclusive to males. However, it was only at the end of the Early Iron Age that occasional females had horse remains deposited in their graves.

\section{Images of Animal Sacrifice}

As previously noted, situla art has provided essential insights into Early Iron Age life. More recently, attention has turned to animals in these scenes and their role in multispecies communities as powerful non-human agents and touchstones in broader belief systems (Frie 2016, 2018a, 2018b, 2019; Laharnar and Turk 2018, pp. 67-74, 103-15; Stipančić 2016b; Teržan 2011, 2012). Situla art does not 
appear to depict scenes of daily life; in fact, many of these scenes seem to be explicitly ritual in nature with a heavy focus on processions, feasting, and other communal celebrations. Procession scenes are particularly interesting for this study - there are many processions of humans and animals depicted, and in several cases, animals are being led or followed by a man armed with an axe (see Figure 1). These scenes have been proposed to represent animals being led to sacrifice (Lücke 2007). Objects depicting animals accompanied by axe men indicate which taxa had a role to play in animal sacrifice, particularly when compared to the faunal remains identified in graves. These situla art scenes also provide insight into the activities that preceded the sacrifice and deposition of the animals discussed in the previous section.

Men carrying axes, leading or following animals, are depicted on five objects (Figures 1 and 6). On four of these objects, the animal is a horse (Figure 1, top; Figure $6 a, b, d$ ), on one there is a sheep (Figure 1, top), and on another, an ibex ${ }^{3}$ and a red deer are recognizable, but the other ungulates cannot be taxonomically defined (Figure 1, bottom). Ungulates whose species cannot be determined appear on three of the five objects (Figure 1, bottom; Figure 6a,c,e).

a)



b)

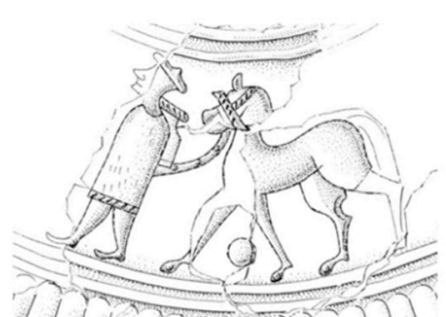

c)

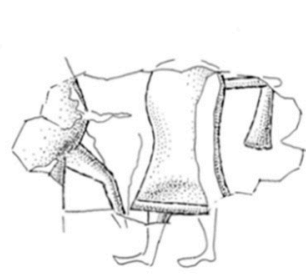

d)
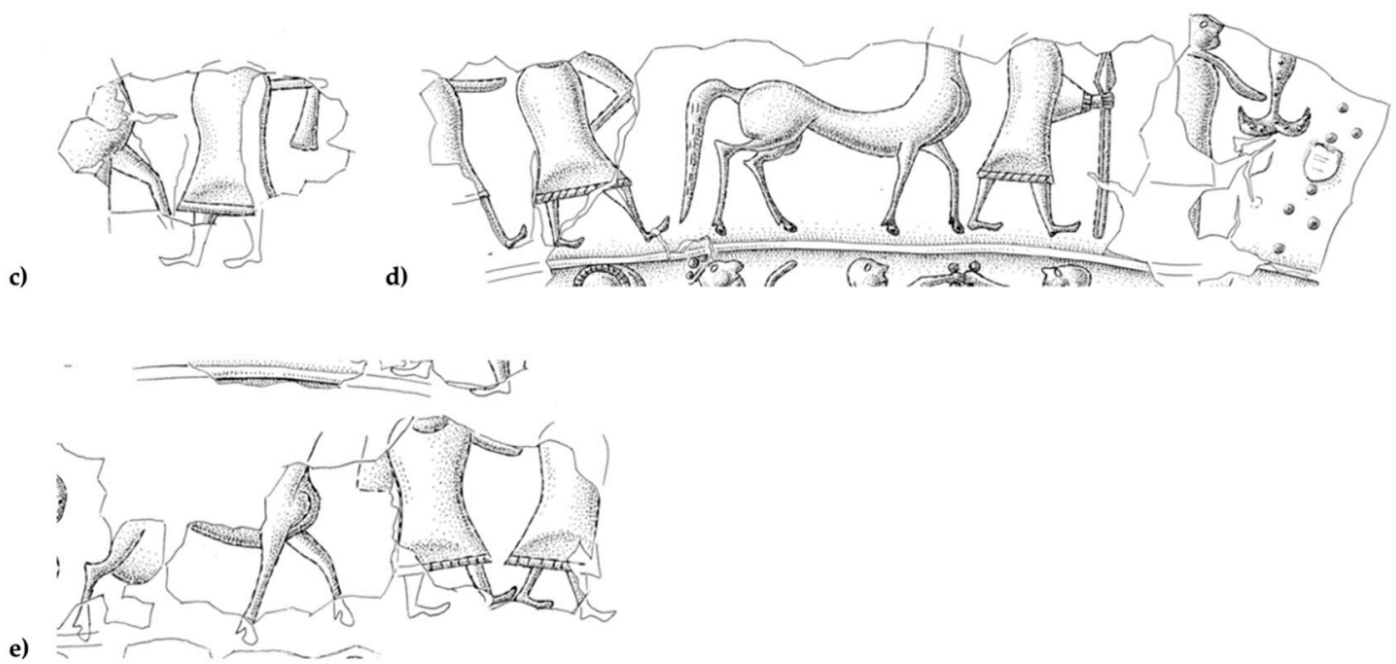

Figure 6. Details of situla art scenes depicting animals with axe men. (a) Situla from Grave III/33 at Novo mesto-Kandija, Dolenjski muzej P 821 (Križ 2012, pp. 72-73); (b) ciborium lid from Grave 2/p at Magdalenska gora-Preloge, Narodni muzej Slovenije P 4282 (Tecco Hvala et al. 2004, Insert 5); (c-e) situla from Grave 2/a at Magdalenska gora-Preloge, Narodni muzej Slovenije P 4280 (Tecco Hvala et al. 2004, Plate 7).

These animals are being led or goaded forward by men carrying axes that would be used in the sacrificial act. Axes recovered from mortuary contexts in other parts of Hallstatt Europe have been

3 It is also possible that this is a goat or chamois, since these are local species with similar horn morphology. However, in other examples of situla art goats have distinctive torqued horns, while the size and shape of the horns on this animal most closely match ibex. Ibex are also clearly identifiable in other situla art scenes, and in this case, ibex seems to be the most plausible identification. 
interpreted as essential tools for the ritual killing of animals, particularly larger species (Arnold 2010, p. 198; Krausse 2007, pp. 220-22; Lücke 2007). This is supported by situla art scenes from neighboring regions, such as the situla from Sanzeno and cist from Eppan, both of which depict a man striking the back of an ungulate with an axe (Lucke and Frey 1962, Plates 62,67).

Axes are not the only indicators of possible sacrifice scenes. Birds are also highly significant in these scenes (Frie 2019). The situlae from Magdalenska gora and Vače depict very similar scenes; both the top and middle registers depict animals that are likely being led to sacrifice (Figure 1). The birds in these scenes mark the sacrificial animals_birds fly above them and perch on their backs, and there are even birds hanging upside down above these animals. Interestingly, despite their extreme similarity, the Vače situla depicts the sacrifice of horses and sheep, whereas the situla from Magdalenska gora depicts the sacrifice of wild animals including ibex and a deer.

Horses are the most recognizable animal depicted in sacrifice scenes on situla art, appearing on three objects (Figure 7). This aligns with the overwhelming significance of horse remains in funerary contexts, including the burials of whole horses (Dular 2007; Frie 2018a; Kmet'ová 2013a, 2013b, 2018; Kmet'ová and Stegmann-Rajtár 2014). Ungulates whose species could not be determined were also frequent because many of these artifacts were damaged, which obscured the figures and made genus- or species-level identification impossible. These ungulates were identified on the basis of the morphology of the preserved figures, most often hooves and legs, but also short tails. While the missing pieces in many cases have been sketched in on the artifact drawings (see Figures 1 and 6), these reproductions are speculative so are not used for the purposes of identifying taxa. Ungulates with short tails are not horses or cattle but could be sheep, deer, or ibex, indicating that while these species are only represented on one artifact each in limited numbers, this is certainly an underrepresentation of their original prevalence in the situla art. These unidentified ungulates could also be other local species including goats or chamois, which are known in situla art outside Dolenjska (Lucke and Frey 1962).



Figure 7. Depictions of animal sacrifice in situla art, divided taxonomically.

The Vače situla depicts a ram with prominent testes following a man with an axe (see Figure 1, top). There are very few animals depicted with genitalia in Dolenjska Hallstatt imagery, and it was a specific choice to highlight that this was an intact ram, especially if wethers and ewes dominated flocks, as is often the case with wool flocks (Calder 2011, pp. 19-20; Clutton-Brock 1981, p. 25). It may 
also have served to highlight certain attributes of rams-possibly their protectiveness of their flocks or their virility (Calder 2011, p. 32).

Red deer are identifiable in situla art on the basis of their antlers, and they most often appear in processions and hunting scenes, as well as the single scene of animal sacrifice (Figure 1, bottom). This is the only scene of its kind in the Dolenjska Hallstatt repertoire; however, it does have important parallels in the Etruscan world. Initially, this scene seems unlikely to portray a real event, because it would be difficult to capture a live deer and transport it for sacrifice without injuring it, and it would be exceptional to harness a deer and lead it tamely to its death (Basson and Hofmeyer 1973, pp. 151-60; Fowler 1995, pp. 57-66). However, Etruscan art depicts the capture and restraint of deer in multiple images, as well as the use of drive nets that would allow deer to be captured alive (Rask 2014, p. 303). Etruscan art also shows scenes of deer sacrifice, and sanctuaries and graves contained the remains of deer (Rask 2014, pp. 296-307).

There are several explanations that may suit the Dolenjska Hallstatt deer sacrifice imagery. It is possible that the artisan who created the situla or those who commissioned it were familiar with Etruscan practices or images, and this scene is specifically intended to reference such models. It may also be that Dolenjska Hallstatt peoples captured and sacrificed deer as well, though because this is the only extant scene, we cannot be sure. Horse sacrifice is more clearly attested because the imagery and intact bodies of horses support the likelihood that they were graveside sacrifices, while no intact deer are currently known from mortuary contexts and deer remains in graves are relatively rare (Table A1). It is also possible that deer sacrifice was not practiced by local people, and instead, this scene purposefully portrays what was considered an impossible circumstance, possibly intended as a mythological scene or to depict extreme control over nature through the provision of an extraordinary sacrifice.

The situla from Grave 13/55 at Preloge near Magdalenska gora is very unusual; it shows a harnessed ibex being led by a man, followed by a second ibex (see Figure 1, bottom). This scene likely indicates that the ibex were being taken for sacrifice, because it mirrors scenes with horses and axe men. Capturing ibex for sacrifice would present even more difficulties than capturing deer. In addition to the difficulty of capturing a live animal, ibex would have been very difficult to access because ibex are well equipped to escape to cliffsides humans cannot easily reach, live in less accessible regions, and would need to be transported quite a distance to reach sites in Dolenjska or Bela krajina for sacrifice. It is also possible wild animals were occasionally tamed and later sacrificed. Whether tamed or captured alive for sacrifice, these represent extraordinary human-animal interactions.

Interestingly, though cattle and pigs appear in the faunal dataset from mortuary contexts and are the most important Dolenjska Hallstatt subsistence animals, depictions of these animals are exceedingly rare and entirely absent from sacrifice scenes (Bartosiewicz 1996, pp. 30, 33; Frie 2017, pp. 115-18, 124, 238). It is unclear whether this is simply due to a limited iconographic dataset or a more meaningful pattern reflecting the ritual status of cattle and pigs and their involvement in animal sacrifice.

\section{Discussion}

The significance of Dolenjska Hallstatt animal sacrifice has been overlooked in part due to the tendency to study faunal remains and imagery separately. Scenes of animal sacrifice appear on only five objects, but there are important connections between the species depicted in these images and the faunal remains in grave contexts. An additional issue is that many of the graves containing animal remains were excavated by antiquarians, who left partial notes or who did not preserve the animal bones for future analysis. Nonetheless, when these data are considered in the aggregate, it becomes clear that animals were a key part of certain funerary performances, and animal sacrifice was an important part of ritual practice. Based on the remains in this sample, there are important distinctions between the burial of whole horse bodies, animal parts, and specific elements such as teeth and claws. It is suggested that these variable treatments of animal bodies related to different aspects of managing death in the local community and demonstrate the varied relationships that characterized Early Iron Age multispecies communities. 


\subsection{Depositions of Animal Parts}

Though the deposition of partial animal remains requires the death and disarticulation of an animal, these finds are rarely viewed through the lens of animal sacrifice. Indeed, such finds are often presented as food offerings or feasting refuse, as if such finds are purely mundane. In reality, finds from mortuary contexts are never mundane, and the juxtaposition of recently deceased humans and animals deserves explicit attention. We should consider the fact that animal sacrifice comes in a variety of forms across the spectrum of formality (Ekroth 2014; Pluskowski 2012). Feasts may include elements of animal sacrifice, because a key aspect of animal sacrifice is the ritual killing of an animal and consumption of its flesh (Hamilakis and Konsolaki 2004, p. 145). The divide between sacrifice and normal slaughter may also be a modern distinction; in some cultures, the killing of animals is always a ritualized practice (Morris 2012, pp. 17-18).

The significance of animal parts in Dolenjska Hallstatt ritual has been overlooked because archaeologists have found depositions of whole animals more theoretically compelling, leaving partial remains under-considered (Valera and Costa 2013, p. 272). This is evidenced by the small sample of analyzed animal parts from burial contexts. Horse bodies are easier to discuss here because when they have been found associated with graves, they were more likely to be analyzed and published, whereas other animal parts are often just a footnote. However, more recent treatment of parts versus wholes highlights that meaningful parts may constitute the whole (Chapman 2000a; Chapman and Gaydarska 2007). The insight provided by such work is that parts or fragments may maintain the same symbolic significance as the whole and, in fact, may be a key element of a distributed whole that enchains a network of relationships. As António Valera and Cláudia Costa state in their discussion of segmented animal bodies from burials in southern Portugal, "the parts, by participating in the essence of the whole, play the social role of maintaining connections between people or between people and places or events" (Valera and Costa 2013, p. 272). This was all part of a process of enchainment, and the act of fragmenting animal bodies was one way of materializing these enchained relationships (Brittain and Harris 2010, pp. 586-87). It is likely that participation in the ritual sacrifice and division of animals drew together living and dead humans and animals and implicated a whole network of relationships in a multispecies community (Boyd 2017, pp. 307-9; Hamilakis and Overton 2013; Mlekuž 2013; Watts 2013).

Timothy Insoll's ethnoarchaeological work on the ritual of animal sacrifice among the Talensi in Ghana (2010) has demonstrated that sacrifice and partition, despite its ritual significance, may not appear in the archaeological record as obviously distinct from other faunal remains. Animal sacrifice may only appear as a few discrete animal parts or even as food refuse, if it is archaeologically visible at all (Insoll 2010, pp. 238-39). Insoll's work demonstrates that animal sacrifice and the distribution of animal parts post-ritual may be essential to distribute ritual efficacy. The distribution also literally materializes kin and community ties and, in doing so, strengthens them. The division of sacrificial animals makes a statement about relationships, and due to the aforementioned ontological parity between part and whole (or at least referential significance of part to whole), it draws members of the community together (Valera and Costa 2013, p. 272).

Dolenjska Hallstatt animal sacrifice associated with funerary ritual may have served as an explicit reference to the community membership of the decedent, which was materialized by sacrificing and dividing an animal and depositing a part in their grave. Just as it may have been their right in life to receive certain parts of an animal post-sacrifice, it may have been important to materialize this again as the individual left the realm of the living (Chapman 2000b, p. 6; Härke 2014, p. 50). This may have been a key moment for the reconfiguration of social ties in which the appropriate distribution of animal parts to individuals shifted to account for this new community with one less living member. While it is not possible to test the veracity of this hypothesis about animal sacrifice and division, the presence of partial faunal remains in graves indicates probable sacrifice and certainly the division of animals associated with funerary ritual. 
Not only can animal sacrifice be a way of materializing and reinforcing community ties, but Insoll's ethnoarchaeological research indicates that it may also be essential for the management of death. It is possible that the ritual of animal sacrifice had the explicit or implicit goal of assuaging the negative forces associated with death and of warding off similar events in the future (Brück 1999, p. 320; Insoll 2010, p. 242). Animal sacrifice for community membership and mitigating negative forces are not mutually exclusive explanations, and the reasoning behind animal sacrifice likely varied according to the circumstances (Frie 2016).

In the Dolenjska Hallstatt culture, the slaughter of an animal and its placement in a grave indicates that animal sacrifice was an important form of ritual expression. This is reflected in situla art as well-primarily horses, but also ibex, deer, and a sheep are shown being led to their death in the company of a man with an axe. Horses and sheep were local animals, and the sacrificed animals were almost certainly known to those participating in the funeral and possibly to the deceased as well. These rituals drew on and materialized multispecies relationships through the incorporation of animals, bringing together humans and non-humans, the living and the dead.

\subsection{Whole Animals}

Horses are notable for being buried whole in elite male graves in the Dolenjska Hallstatt culture (Dular 2007; Frie 2018a; Kmet'ová 2013a, 2013b; Kmet'ová and Stegmann-Rajtár 2014). Such depositions, often referred to as associated bone groups in the zooarchaeological literature, are generally taken to indicate the sacrifice of an animal rather than its death of natural causes (Morris 2008, 2011; Pluskowski 2012, p. 2). The sacrifice of a horse during the funeral of an elite male displayed the individual's status by marking their association with this restricted animal in life while also taking this valuable animal to the grave with them in the ultimate act of conspicuous consumption (Frie 2018a). References in Indo-European mythology and the significance of horse burials throughout Bronze and Iron Age Europe have led to the proposal that such rituals were regulated by sumptuary rules where only certain high-status individuals could have a horse sacrifice associated with their burial, linking the deceased with heroic ancestors and gods who were also carried to the afterlife on horseback or in chariots and wagons (Armstrong Oma 2013; Azzaroli 1980; Carstens 2005; Kmet'ová 2013b, pp. 73-76; 2018; Kmet’ová and Stegmann-Rajtár 2014, p. 162; Kossack 1998; Kuzmina 2006, pp. 263-65).

The evidence from iconography as well as the association of whole horses with higher-status males supports the assertion that cosmology and status provided an important impetus for the sacrifice of a horse during certain funerary events. However, another facet of human-horse relations should be considered to explain why horses in particular were so important in the funerary rituals of certain individuals. In a previous article I proposed that the status of these elites was related to their unique relationship with horses (Frie 2018a). Horses were a restricted animal, but they were also involved in highly social one-on-one relationships with their riders that contained elements of care, control, communication, and mutual action (Argent 2010, 2012; Game 2001) —-this would have set riders apart from others in their community, perhaps even reinforcing the unique social position of the horse and rider, who shared a relationship completely distinct from other human-animal interactions (Frie 2018a).

It has been suggested that finds of elderly or lame horses indicates that people were choosing less economically significant horses to sacrifice (Bökönyi 1968, p. 11-15; Tecco Hvala 2012, p. 29). However, in Sándor Bökönyi's assessment of the horse remains from Magdalenska gora, Stična, and Brezje pri Trebelnem, only one horse was identified as old with clear pathologies (Bökönyi 1968, p. 13). This was one of four horses found with two males in Grave V/29 at Magdalenska gora (Hencken 1978, pp. 36-38). Though most of the horses analyzed by Bökönyi were identified as adults, it does not follow that these were less economically significant animals. Adult horses are more likely to be well trained and, importantly, well known to the local community. It may even be that the old stallion in Grave V/29 was a favored steed and longtime companion of one of the men in this grave, rather than an old horse that could be sacrificed because it no longer served a purpose. 
Two of the earliest horse burials, Grave 17/6 from Grmada near Molnik and Grave VI/5 at Gomile near Brezje pri Trebelnem, are distinguished by the combination of cremated horse bones and human bones-it is possible that human and horse were cremated on the same pyre. Cremation of the dead is a labor-intensive performative ritual that is sensuously affective upon the audience (Williams 2004). The entire performance, from the building of the pyre to the cremation itself and the final recovery of select bones from man and beast is best understood as "scene-making", because a cremation was "clearly intended to be remembered by mourners, not through its endurance and permanence, but through its brief visibility and subsequent destruction" (Williams 2004, p. 271). The combination of man and horse-either cremated separately or together, would have been a powerful sensory experience for the observers (Frie 2016, pp. 74-75). However, despite the extraordinary and likely memorable nature of these events, after the local Podzemelj phase (circa 800-720 вСЕ), there are no other co-mingled human-animal cremations known from this area.

There were four burials of solely horses without a human in the grave-Graves 5/10 and 48/Horse Grave 71 from Stična and Graves 2 and 3 from Tumulus VI at Brezje pri Trebelnem (Dular and Križ 1990, p. 537; Gabrovec and Kruh 2006a, p. 139; 2006b, p. 56; Kromer 1959, p. 21). The burial of horses without associated humans was clearly a unique treatment and may indicate that a human-like status was granted to particular horses. Two of these burials included grave goods: Grave 5/8 contained a bronze button and iron ring, likely from a harness, along with an iron awl, a wooden stick, and a footed ceramic vessel, while Grave VI/2 contained two iron spearheads. These artifacts are comparable to finds from human graves of this period, highlighting the continuity between human and non-human members of the community. What is not clear is whether or not these horses were sacrificed prior to their burial at these two sites and if these burials of solely horses are analogous to the burials of horses with humans or represent a distinct mortuary practice. Whether sacrificial animals or not, these four horses were likely known, valued members of the community, buried with respect similar to the humans they were buried near and were perhaps even mourned.

Three Dolenjska Hallstatt graves in the study contained dog remains. Two of these, both from Preloge at Magdalenska gora, contained a dog canine that was likely worn as a pendant or amulet (Škvor Jernejčič and Toškan 2018, p. 6). The third instance of dog remains in a burial comes from Grave I/13 at Vir near Podzemelj. Not much is known about these remains because they were identified during an antiquarian excavation, but the "skeleton of a large dog" was noted (Barth 1969, p. 149). This represents an entirely different funerary ritual, where a dog was likely sacrificed to be interred with the deceased individual. In other archaeological contexts, burials of dogs and humans together, particularly intact dogs, are taken to indicate companionship and potentially even the role of a pet (Horard-Herbin et al. 2014, p. 28; Morey 2006, pp. 159-66). Interestingly, this burial is the only potential evidence of dogs as pets in this period-situla art only depicts them in hunting contexts, never in more domestic or communal scenes (Frie 2017, pp. 322-25). Even if dogs were primarily kept as working animals, it is plausible that some dogs had a close, companionable relationship with humans. Grave I/13 from Vir may be the ultimate expression of this relationship, where the dog was sacrificed to remain the deceased's companion in death, analogous to what is seen with horses, but it may also be due to other attributes of the dog or the human decedent. Without comparable cases, it is difficult to interpret the significance of this unusual find.

\subsection{Animals as Amulets}

Ludwig Pauli proposed that teeth, claws, and single animal bones from Hallstatt graves served as amulets, in addition to other items such as glass and amber beads (1975). Pauli's work demonstrates that amulets were most often associated with women and children, populations he identifies as those most likely to need extra protection (Pauli 1975, p. 154). The popularity of teeth in this dataset matches Pauli's findings. Boar tusks and bear canines were most prevalent in his study, which he associates with male warriors and ideals of strength, courage, and bravery, which could also apply to the Dolenjska Hallstatt examples (Pauli 1975, pp. 129-30). 
No children have been identified with animal amulets in this study, and more male graves contain such finds than female graves. There are only a few possible amulets associated with female graves, all from Preloge at Magdalenska gora: one grave with horse teeth, a grave with a horn, and a grave with a dog canine. The association of teeth and claws primarily with males rather than females and children does not negate the possibility that such items were used as amulets, but rather, this may indicate that particular men were considered more in need of the type of protection offered by animal amulets.

What is less clear at this point is whether these items belonged to the deceased or if these items were restricted to the mortuary sphere. It is also unclear whether the deposition of these items served to protect the dead or to protect the living from the dead. The strong focus on teeth is notable; these may have been considered especially important compared to other elements (Choyke 2010). The pendants made from dog canines at Magdalenska gora may reference the role of dogs as hunters and the power of their jaws and teeth (Choyke 2010), which may also be the reason a bear claw was chosen as an amulet. The focus on animal teeth, particularly those of ruminants, is shared by neighboring Hallstatt cultures in the region of modern Slovenia, including the Ljubljana group and Sveta Lucija group (Gruškovnjak 2016, pp. 445-47). The use of teeth is interesting for another reason, because the harvesting of teeth would have required intensive or prolonged engagement with animal remains. Teeth are difficult to remove from a recently deceased animal without significant processing to open the alveolar processes and separate the ligaments holding the teeth in place. It is easier to remove animal teeth from a long-dead, defleshed animal after the soft tissue has broken down. This requires us to consider that either (1) past peoples were engaging in messy, relatively labor-intensive extraction of animal teeth or (2) deceased animals or animal parts were accessible during or after the process of decomposition to access teeth. In either case, we need to expand our perspective on ancient human-animal relations to include not just living animals, but also drawn-out engagements with deceased animals as socially and ritually significant.

\section{Conclusions}

Dolenjska Hallstatt peoples maintained significant, life-long relationships with local animals. Animals were raised from birth, cared for, and known as individuals with distinct personalities and life histories (Argent 2010; Frie 2016, 2018a; Mlekuž 2013). Whether wild or domestic, living or deceased, animals were essential parts of Dolenjska Hallstatt communities, and this significance was materialized by their sacrifice during funerary rituals.

Animal sacrifice may seem callous or distasteful to us, because we are often shielded from the reality of animal lives and deaths. However, in small communities that raised and cared for these animals for years, killing them likely had different connotations. Killing an animal in an agrarian context is the final stage in a long-term relationship, and the animal's meat may be seen as an appropriate exchange for the care and protection given the animal throughout its life (Bock et al. 2007; Theodossopoulos 2005, p. 24). There may be elements of sadness or regret that mark the end of such relationships; however, this is nonetheless the natural and expected end of their life. In the Dolenjska Hallstatt case, it was likely exceptional when such events were tied to the death of a human member of the community.

The act of sacrifice juxtaposed the deaths of familiar humans and animals. Horses may have been viewed as companions in death as they had been in life. In turn, the sacrifice of an animal or animals during the funerary ritual and the division of its parts may have been essential for assuaging negative forces associated with death or for the management of group ties necessitated by the loss of a community member. The placement of animal parts in graves marked the membership of the decedent in the community and may have begun the process whereby social ties were reconfigured. Particular elements such as teeth or horns and claws may have served as amulets-possibly indicating that they were personal items that had to be placed in the grave with the deceased or that the deceased needed continued protection or other symbolic aid. Whatever the case may be, it is clear that animals 
were significant in Iron Age communities and that we still have much to learn about their role in the mortuary sphere.

Funding: This research was funded by the Wenner-Gren Foundation, Dissertation Fieldwork Grant No. 9038 and a University of Wisconsin-Milwaukee Distinguished Dissertation Fellowship.

Acknowledgments: Access to artifacts and archival material was kindly provided by Peter Turk and Vesna Svetličič Turk at the Narodni muzej Slovenije, Borut Križ and Petra Stipančić at the Dolenjski muzej, Anton Kern and Walpurga Antl-Weiser at the Naturhistorisches Museum Wien, Marko Mele at the Universalmuseum Joanneum Graz, and Susan Haskell and Laura Costello at the Peabody Museum of Archaeology and Ethnology at Harvard University. Bettina Arnold and Sneža Tecco Hvala kindly mentored me throughout this project and provided essential access to scholarly networks and resources. Borut Toškan and Jean Hudson also provided very helpful advice navigating the zooarchaeological dataset. Kevin Garstki and the anonymous reviewers provided thoughtful feedback that helped refine the paper; I appreciate their time and assistance. Any mistakes or omissions are my own.

Conflicts of Interest: The author declares no conflict of interest. The funders had no role in the design of the study; in the collection, analyses, or interpretation of data; in the writing of the manuscript; or in the decision to publish the results. 


\section{Appendix A}

Table A1. Mortuary contexts with zooarchaeological remains.

\begin{tabular}{|c|c|c|c|c|c|}
\hline Site & Grave & Species & MNI $^{1}$ & Elements & $\begin{array}{l}\text { Associated Human Burial } \\
\text { (Probable Gender/Age) }^{2}\end{array}$ \\
\hline \multirow{3}{*}{ Molnik_Grmada } & \multirow{3}{*}{$17 / 6$} & Horse & 1 & $\begin{array}{l}\text { Tooth, humerus }(\mathrm{L}) \text {, ulna }(\mathrm{L}) \text {, radius, metacarpal }(\mathrm{R}) \text {, carpal }(\mathrm{L}) \text {, } \\
\text { sesamoid, femur }(\mathrm{R}) \text {, metatarsal }(\mathrm{L}) \text {, calcaneus }(\mathrm{L}) \text {, tarsal }(\mathrm{L}) \text {, tarsal } \\
(\mathrm{R}) \text {, phalanx }\end{array}$ & \multirow{3}{*}{$o^{7} /$ Adult } \\
\hline & & Pig & 1 & Humerus (L), cervical vertebra & \\
\hline & & Indeterminate $^{3}$ & $\mathrm{~N} / \mathrm{A}^{4}$ & Cranial fragments, rib fragments, indeterminate elements & \\
\hline \multirow{2}{*}{ Vače-Apno } & \multirow{2}{*}{ Finds above graves $12-24$} & Megalodon shark & 1 & Tooth & \multirow{2}{*}{ N/A-stray find } \\
\hline & & Cattle & $1 ?$ & "Calves' bones" (Starè 1955, p. 125) & \\
\hline Vače-Reber & Cremation Grave 2 & Deer (unknown species) & $1 ?$ & "The bones of the legs of a deer" (Starè 1955, p. 72) & \%/Indt. \\
\hline Zagorje ob Savi & $\begin{array}{l}\text { Milač House/Grave with } \\
\text { the Belt Plate }\end{array}$ & Horse & $1 ?$ & “The leg bones of a horse" (Draksler 2007, p. 131) & $\sigma^{x} /$ Adult \\
\hline \multirow{7}{*}{$\begin{array}{l}\text { Magdalenska } \\
\text { gora-Laščik }\end{array}$} & $\mathrm{V} / 2$ & Roe Deer & 1 & Metatarsals & \%/Adult \\
\hline & $\mathrm{V} / 5$ & Horse & 1 & Upper M3 (R), lower M2 (R) & Indt./Indt. \\
\hline & $\mathrm{V} / 6-7-7 \mathrm{a}$ & Horse & 1 & $\begin{array}{l}\text { Exact elements unknown, excavation photograph shows full } \\
\text { articulated skeleton }\end{array}$ & $\mathrm{o}^{\top} /$ Adult \\
\hline & $\mathrm{V} / 11$ & Brown Bear & 1 & Claw & $o^{3} /$ Adult \\
\hline & $\mathrm{V} / 19-20$ & Indeterminate & 1 & Indeterminate fragment & $\sigma^{x} \sigma^{x} /$ Adult \\
\hline & $\mathrm{V} / 29$ & Horse & 4 & $\begin{array}{l}\text { Horse 1: Tibia (R) } \\
\text { Horse 2: Cranial fragments, mandible, vertebrae, sacrum, scapulae, } \\
\text { humeri, radii, ulnae, metacarpals, innominates, femurs, tibiae, } \\
\text { astragalus and calcaneus (R), metatarsals } \\
\text { Horse 3: Upper incisors, canines, premolars, molars, mandible, } \\
\text { vertebrae, sacrum, rib fragments, scapula (L), humeri, radii, ulnae, } \\
\text { metacarpals and phalanges, innominates, femurs, patellae, tibiae, } \\
\text { metatarsals and phalanges } \\
\text { Horse 4: Scapula fragment, femur (L), tibiae, astragalus (L), calcanei, } \\
\text { metatarsal (R) }\end{array}$ & \multirow[t]{2}{*}{$\sigma^{x} \sigma^{x} /$ Adult } \\
\hline & & Indeterminate & 1 & Pierced bone pendant & \\
\hline
\end{tabular}


Table A1. Cont.

\begin{tabular}{|c|c|c|c|c|c|}
\hline Site & Grave & Species & $\mathrm{MNI}^{1}$ & Elements & $\begin{array}{l}\text { Associated Human Burial } \\
\text { (Probable Gender/Age) }^{2}\end{array}$ \\
\hline \multirow{22}{*}{$\begin{array}{l}\text { Magdalenska } \\
\text { gora-Preloge }\end{array}$} & $2 / 13$ & Horse & $1 ?$ & $\begin{array}{l}\text { Mandible, teeth, unknown elements. Full skeleton implied } \\
\text { (Tecco Hvala 2012, p. 31) }\end{array}$ & $o^{\top} /$ Adult \\
\hline & $2 / 57$ & Horse & $1 ?$ & "Horse skeleton" (Tecco Hvala 2012, p. 31) & $\sigma^{x} /$ Indt. \\
\hline & $2 / 69$ & Unknown & $1 ?$ & Teeth & $o^{7} /$ Indt. \\
\hline & $2 / 88$ & Horse & $1 ?$ & Teeth & Indt./Adult \\
\hline & $13 / 87$ & Dog & 1 & Canine tooth & q/Adult \\
\hline & $13 / 119$ & Horse & $1 ?$ & "Parts of a horse skeleton and teeth" (Tecco Hvala 2012, p. 31) & $o^{\top} /$ Adult \\
\hline & $13 / 132$ & Goat & 1 & Horn & $\sigma^{\top} /$ Adult \\
\hline & $13 / 163$ & Sheep/Goat & $1 ?$ & "Bones of a caprovid" (Tecco Hvala 2012, p. 31) & o/Indt. \\
\hline & $\mathrm{II} / 17$ & $\begin{array}{c}\text { Bovid } \\
\text { (indt. species) }\end{array}$ & $1 ?$ & “Two worked pieces of horn" (Hencken 1978, p. 15) & q/Adult \\
\hline & $\mathrm{IV} / 30$ & Horse & $1 ?$ & Unknown $^{5}$ & $\sigma^{\top} /$ Adult \\
\hline & $\mathrm{IV} / 32$ & Horse & 1 & Rib, scapula, vertebrae & $\sigma^{\pi} /$ Indt. \\
\hline & $\mathrm{IV} / 40$ & Horse & $1 ?$ & Unknown $^{6}$ & Indt./Indt. \\
\hline & & Cattle & 7 & Astragali (7 L and $2 \mathrm{R}$ ), calcanei (L and R), centrotarsal (L) & \\
\hline & IV/43 & Horse & 1 & $\begin{array}{l}\text { Cranial fragments, deciduous and permanent upper premolars, } \\
\text { permanent upper molars, mandible, deciduous lower incisor, } \\
\text { deciduous and permanent lower premolars, permanent lower } \\
\text { molars, vertebrae, rib fragment, scapula fragments, humeri, radii, } \\
\text { ulnae, carpals, metacarpals and phalanges, innominates, femurs, } \\
\text { patellae, tibiae, astragali, calcanei, tarsals, metatarsals, phalanges }\end{array}$ & $o^{7} /$ Indt. \\
\hline & $\mathrm{VII} / 29$ & Sheep/Goat & 1 & Vertebra & Indt./Adult \\
\hline & $\mathrm{VII} / 38$ & Roe Deer & 1 & Cranial fragment $(\mathrm{L})$ & Indt./Adult \\
\hline & $\mathrm{VII} / 39$ & Horse & $1 ?$ & "Some bones and teeth" (Hencken 1978, p. 58) & $\sigma^{\prime} /$ Adult \\
\hline & $\mathrm{VII} / 51$ & Dog & 1 & Canine tooth & $\sigma^{\top} /$ Indt. \\
\hline & $\mathrm{X} / 14$ & Horse & 1 & Lower M3 (L) & Indt./Adult \\
\hline & $\mathrm{X} / 18$ & Horse & 1 & Upper premolar (L) & F/Adult \\
\hline & $\mathrm{X} / 28$ & Horse & 1 & Upper M3 (R) & $\sigma^{7} /$ Adult \\
\hline & $\mathrm{X} / 52$ & $\begin{array}{c}\text { Suid } \\
\text { (indt. species) }\end{array}$ & $1 ?$ & Unknown $^{7}$ & $\sigma^{\pi / A d u l t}$ \\
\hline
\end{tabular}


Table A1. Cont.

\begin{tabular}{|c|c|c|c|c|c|}
\hline Site & Grave & Species & MNI $^{1}$ & Elements & $\begin{array}{r}\text { Associated Human Burial } \\
\text { (Probable Gender/Age) }^{2}\end{array}$ \\
\hline \multirow{17}{*}{ Stična-Gomile } & $5 / 8$ & Horse & 1 & Horse skeleton & None $^{8}$ \\
\hline & $5 / 10$ & Horse & $1 ?$ & "Long and single flat bones" (Gabrovec and Kruh 2006a, p. 139) & Indt./Adult \\
\hline & \multirow{2}{*}{$48 / 33^{9}$} & Horse & 1 & Horse skeleton & \multirow{2}{*}{$\sigma^{7} /$ Adult } \\
\hline & & Horse & 1 & Horse skeleton & \\
\hline & $48 / 46$ & Horse & 1 & Cranium & Indt./Indt. \\
\hline & 48/Find 56 & Horse & $1 ?$ & "Broken bones—(from animals?)" (Gabrovec and Kruh 2006b, p. 52) & N/A-stray find \\
\hline & $\begin{array}{l}\text { 48/Horse } \\
\text { Grave } 71\end{array}$ & Horse & 1 & Horse skeleton & None $^{8}$ \\
\hline & 48/Find 77 & Unknown & $1 ?$ & "Animal bones" (Gabrovec and Kruh 2006b, p. 63) & N/A-stray find \\
\hline & 48/Find 93 & Unknown & $1 ?$ & "Animal bone fragments" (Gabrovec and Kruh 2006b, p. 72) & N/A-stray find \\
\hline & \multirow{2}{*}{$48 / 104$} & Horse & 1 & "Chest and vertebrae" (Gabrovec and Kruh 2006b, p. 79) & \multirow{2}{*}{$\sigma^{7} /$ Adult } \\
\hline & & Unknown & $\mathrm{N} / \mathrm{A}^{10}$ & "Pile of burnt animal bones" (Gabrovec and Kruh 2006b, p. 79) & \\
\hline & $48 / 115$ & Unknown & $1 ?$ & "Animal bones" (Gabrovec and Kruh 2006b, p. 86) & Indt./Indt. \\
\hline & $\mathrm{III} / 2 \mathrm{c}$ & Horse & $1 ?$ & "Animal bones and several teeth" (Wells 1981, p. 54) & Indt./Indt. \\
\hline & $\mathrm{IV} / 16$ & Horse & 1 & $\begin{array}{l}\text { Upper and lower premolars and molars, rib fragment, scapula } \\
\text { fragment (L), humerus fragment }(\mathrm{R})\end{array}$ & $\sigma^{\pi / A d u l t}$ \\
\hline & IV/47 & Horse & 1 & Maxillary fragments, upper premolars and molars, tibia (R) & \%/Indt. \\
\hline & V/Isolated Finds & Horse & 1 & Teeth & N/A-stray find \\
\hline & $\mathrm{VIII} / 2$ & Horse & 1 & Mandible & Indt./Indt. \\
\hline Medvedjek & $\mathrm{I} / 36$ & Horse & 1 & Maxillae, upper teeth, mandible, lower teeth & Indt./Indt. \\
\hline \multirow{8}{*}{ Libna-Špiler } & $\mathrm{I} / 4$ & Horse & 1 & Temporal, 21 teeth, mandible, two vertebrae & Indt./Indt. \\
\hline & $\mathrm{I} / 6$ & Horse & 1 & 12 teeth & $o^{7} /$ Indt. \\
\hline & J/Stray Find & Horse & N/A & Four molars & \multirow{2}{*}{ N/A—stray find } \\
\hline & 1/Stray Fina & Unknown & $\mathrm{N} / \mathrm{A}^{11}$ & Teeth & \\
\hline & $\mathrm{II} / \mathrm{d}$ & Horse & $1 ?$ & Teeth & $\sigma^{7} /$ Indt. \\
\hline & $\mathrm{II} / 1$ & Horse & $1 ?$ & Cranium & $o^{n} /$ Indt. \\
\hline & III/Find 16 & Horse & $\mathrm{N} / \mathrm{A}^{12}$ & Teeth & N/A-stray find \\
\hline & III/Find 25 & Horse & $1 ?$ & Cranium and teeth & N/A-stray find \\
\hline
\end{tabular}


Table A1. Cont.

\begin{tabular}{|c|c|c|c|c|c|}
\hline Site & Grave & Species & $\mathrm{MNI}^{1}$ & Elements & $\begin{array}{l}\text { Associated Human Burial } \\
\text { (Probable Gender/Age) }^{2}\end{array}$ \\
\hline \multirow{3}{*}{$\begin{array}{l}\text { Libna_Volčanškova } \\
\text { gomila }\end{array}$} & 1889-1890/aa & Horse & $1 ?$ & Cranium, ribs, upper limbs & $\sigma^{7} /$ Indt. \\
\hline & 1889-1890/i & Horse & $1 ?$ & Horse skeleton & Indt./Indt. \\
\hline & $\begin{array}{l}\text { 1889-1890/ Unknown } \\
\text { provenience }\end{array}$ & Goat & $1 ?$ & Mandible, "other bones" (Guštin 1976, p. 30) & N/A-stray find \\
\hline \multirow{4}{*}{ Brezje pri Trebelnem } & \multirow{2}{*}{$\mathrm{VI} / 1-2^{13}$} & \multirow{2}{*}{ Horse } & \multirow{2}{*}{3} & $\begin{array}{l}\text { 1. Cranial fragments, mandible, vertebrae, humerus (L), radii, } \\
\text { metacarpal (L), femurs }\end{array}$ & Grave 1: $\sigma^{\top} /$ Adult \\
\hline & & & & $\begin{array}{l}\text { 2. Right upper premolar and molars, mandible, atlas } \\
\text { 3. Radius fragment }(\mathrm{R})\end{array}$ & Grave 2: Horse \\
\hline & $\mathrm{VI} / 3$ & Horse & $1 ?$ & Horse skeleton & None $^{8}$ \\
\hline & $\mathrm{VI} / 5$ & Horse & $1 ?$ & Cremated horse bones & $o^{7} /$ Indt. \\
\hline Novo mesto-Kandija & $\mathrm{VI} / 3$ & Horse & 1 & Cranium & $\sigma^{\top}$ P/Adult \\
\hline \multirow{3}{*}{$\begin{array}{l}\text { Novo mesto-Kapiteljska } \\
\text { njiva }\end{array}$} & I/Central Grave & Horse & 1 & Maxilla (L), mandible (L), loose incisors & Indt./Adult \\
\hline & $\mathrm{XVI} / 11$ & Horse & 1 & Teeth, mandible fragments & Indt./Indt. \\
\hline & $\mathrm{XVI} / 34$ & Horse & $1 ?$ & Teeth, other bones & F/Adult \\
\hline \multirow{2}{*}{$\begin{array}{c}\text { Novo } \\
\text { mesto-Malenškova njiva }\end{array}$} & Malenškova gomila/1 & Horse & $1 ?$ & "Horse bones" (Dular 2007, p. 739 fn. 5) & $o^{n} /$ Indt. \\
\hline & Malenškova gomila/3 & Horse & 1 & Cranium & $o^{7} /$ Indt. \\
\hline Podzemelj-Vir & $\mathrm{I} / 13$ & Dog & $1 ?$ & "Skeleton of a large dog" (Barth 1969, p. 149) & Indt./Indt ${ }^{14}$. \\
\hline
\end{tabular}

1 The minimum number of individuals (MNI) can only be approximated in many cases because zooarchaeological analysis was never conducted on the majority of these remains. The MNI has been labeled with a question mark to indicate that it is an estimation that has not been confirmed in cases where there was no analysis, there was no intact skeleton noted, or there was more than a single element. Number of identified specimens (NISP) is not addressed in this study, though these data were collected. NISP was not consistently available for mortuary contexts, particularly because antiquarian excavations left very sparse notes concerning faunal remains, e.g., "the bones of the legs of a deer", which do not allow for the accurate assessment of NISP. However, the MNI is more appropriate for this study of mortuary contexts because graves are discrete contexts, and it is plausible to assume that animal remains inside a grave constitute an MNI of one. $2 \sigma^{7}$ is used to indicate a probable male decedent, while oindicates a probable female. ${ }^{3}$ This is identified as an "indeterminate" rather than "unknown"

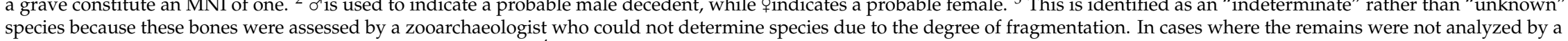
species because these bones were assessed by a zooarchaeologist who could not determine species due to the degree of fragmentation. In cases where the remains were not analyzed by a
specialist and species was not determined, "unknown" is used. 4 The remains of this indeterminate species are not counted toward the MNI of this grave, because they may be fragments from either the cremated horse or pig remains and thus cannot conclusively be identified as a separate animal. ${ }^{5}$ Referred to as "Horse Grave I" by the excavator. Other graves designated "horse grave" contained whole horse skeletons (Hencken 1978, p. 22). ${ }^{6}$ Referred to as "Horse Grave III" by the excavator and assumed to contain a full horse skeleton (Hencken 1978, p. 22). ${ }^{7}$ Though Dr. Sándor Bökönyi assessed these remains, he only indicated that they were "Sus" and gave no details as to the elements represented (Bökönyi n.d.). ${ }^{8}$ This is the burial of solely a horse; it is not associated with a human grave. ${ }^{9}$ Grave 48/33 is associated with Horse Graves 31 and 32, which were found immediately outside the stone-lined chamber of Grave 48/33 at the same level. Previously, I have published these as horse graves unassociated with a human grave; however, this was an error (Frie 2018a). 10 The burned animal bones are not counted toward the MNI because they may be fragments from the identified horse remains and cannot conclusively be identified as a separate animal. 11 The stray finds of teeth are not

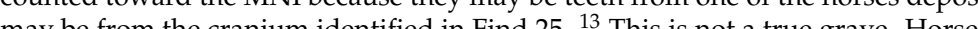
may be from the cranium identified in Find $25 .{ }^{13}$ This is not a true grave. Horse remains from Graves 1 and 2 were mixed in storage and could not be separated. The mixed assemblage
contained bones from three horses, and the aggregate context Grave 1-2 was created to capture these data (Bökönyi 1968, p. 16; Frie 2016, pp. 70-71). ${ }^{14}$ Brina Škvor Jernejčič and Borut Toškan published this grave as the burial of solely a dog without an associated human, noting that the excavator, Szombathy, did not discuss any human remains in his excavation records. However, Szombathy rarely discussed human remains in his excavation notes; they are primarily focused on the artifact assemblage. Based on the rarity of Szombathy noting human remains and the rarity of burials of solely animals (none besides horses are currently known in this area), it is most plausible that this was a burial of both a human and a dog (Škvor Jernejčič and Toškan 2018, pp. 4-5). 


\section{References}

Argent, Gala. 2010. Do the Clothes Make the Horse? Relationality, Roles and Statuses in Iron Age Inner Asia. World Archaeology 42: 157-74. [CrossRef]

Argent, Gala. 2012. Toward a Privileging of the Nonverbal: Communication, Corporeal Synchrony, and Transcendence in Humans and Horses. In Experiencing Animal Minds: An Anthology of Animal-Human Encounters. Edited by Julie A. Smith and Robert W. Mitchell. New York: Columbia University Press, pp. 111-28.

Armstrong Oma, Kristin. 2013. Bronze Age Horses: Beyond Dualist Explanations. In Counterpoint: Essays in Archaeology and Heritage Studies in Honour of Professor Kristian Kristiansen. Edited by Sophie Bergerbrant and Serena Sabatini. Oxford: Archaeopress, pp. 141-46.

Arnold, Bettina. 2001. The Limits of Agency in the Analysis of Elite Iron Age Celtic Burials. Journal of Social Archaeology 1: 210-24. [CrossRef]

Arnold, Bettina. 2006. Gender and Archaeological Mortuary Analysis. In Reader in Gender Archaeology. Edited by Sarah Milledge Nelson. Lanham: AltaMira Press, pp. 137-70.

Arnold, Bettina. 2010. Beasts of the Forest and Beasts of the Field: Animal Sacrifice, Hunting Symbolism, and the Master of Animals in Pre-Roman Iron Age Europe. In The Master of Animals in Old World Iconography. Edited by Derek B. Counts and Bettina Arnold. Budapest: Archaeolingua, pp. 193-210.

Arnold, Bettina. 2011. The Illusion of Power, the Power of Illusion: Ideology and the Concretization of Social Difference in Early-Iron Age Europe. In Ideologies in Archaeology. Edited by Reinhard Bernbeck and Randall H. McGuire. Tucson: The University of Arizona Press, pp. 151-72.

Azzaroli, Augusto. 1980. Venetic Horses from Iron Age burials at Padova. Rivista di Scienze Preistoriche 35: 281-308.

Barth, Fritz Eckart. 1969. Die hallstattzeitlichen Grabhügel im Bereiche des Kutscher bei Podsemel (Slowenien). Bonn: Rudolph Habelt Verlag GMBH.

Bartosiewicz, László. 1991. Faunal Material from Two Hallstatt Period Settlements in Slovenia. Arheološki vestnik 42: 199-206.

Bartosiewicz, László. 1996. Continuity in the Animal Keeping of Hallstatt Period Communities in Slovenia. In Die Osthallstattkultur: Akten des Internationalen Symposiums, Sopron, 10-14 Mai 1994. Edited by Erzsébet Jerem and Andreas Lippert. Budapest: Archaeolingua, pp. 29-35.

Bartosiewicz, László. 1999a. A Systematic Review of Astragalus Finds from Archaeological Sites. In Pannonia and Beyond. Studies in Honour of László Barkóczi. Edited by Andrea H. Vaday. Budapest: Archaeological Institute of the Hungarian Academy of Sciences, pp. 37-44.

Bartosiewicz, László. 1999b. Recent Developments in Archaeozoological Research in Slovenia. Arheološki vestnik 50: 311-22.

Basson, P. A., and J. M. Hofmeyer. 1973. Mortalities Associated with Wildlife Capture Operations. In The Capture and Care of Wild Animals. Edited by E. Young. Cape Town: Human \& Rousseau, pp. 151-60.

Bock, Bettina B., M. M. van Huik, Madeleine Prutzer, Florence Kling Eveillard, and Anne-Charlotte Dockes. 2007. Farmers' relationship with different animals: The importance of getting close to the animals. Case studies of French, Swedish and Dutch cattle, pig and poultry farmers. International Journal of Sociology of Food and Agriculture 15: 108-25.

Bökönyi, Sándor. 1968. Data on Iron Age Horses of Central and Eastern Europe. In Mecklenburg Collection, Part I. Edited by Hugh Hencken. Cambridge: The Peabody Museum, pp. 1-71.

Bökönyi, Sándor. 1994. Analiza živalskih kosti/Die Tierknochenfunde der Siedlung. In Stična I: Naselbinska Izkopavanja/Siedlungsausgrabungen. Edited by Stane Gabrovec. Ljubljana: Narodni Muzej Slovenije, pp. 190-213.

Bökönyi, Sándor. n.d. Letter to Hugh Hencken. Mecklenburg Collection. Box 4, Folder 5. Cambridge: Peabody Museum, Harvard University.

Boyd, Michael J. 2014. The materiality of performance in Mycenaean funerary practices. World Archaeology 46: 192-205. [CrossRef]

Boyd, Brian. 2017. Archaeology and Human-Animal Relations: Thinking through Anthropocentrism. Annual Review of Anthropology 46: 299-316. [CrossRef]

Božič, Dragan. 2009. A Hallstatt grave containing a cuirass, excavated near Stična by the Duchess of Mecklenburg in 1913: The reliability of grave groups from the Mecklenburg Collection. Arheološki vestnik 60: 63-95. 
Brittain, Marcus, and Oliver Harris. 2010. Enchaining arguments and fragmenting assumptions: Reconsidering the fragmentation debate in archaeology. World Archaeology 42: 581-94. [CrossRef]

Brück, Joanna. 1999. Ritual and Rationality: Some Problems of Interpretation in European Archaeology. European Journal of Archaeology 2: 313-44. [CrossRef]

Brumfiel, Elizabeth M. 2006. Methods in Feminist and Gender Archaeology: A Feeling for Difference-And Likeness. In Handbook of Gender in Archaeology. Edited by Sarah Milledge Nelson. Lanham: AltaMira Press, pp. 31-58.

Burmeister, Stefan. 2000. Geschlecht, Alter und Herrschaft in der Späthallstattzeit Württembergs. Tübinger Schriften zur Ur- und Frühgeschichtlichen Archäologie 4. München: Waxmann Münster.

Calder, Louise. 2011. Cruelty and Sentimentality: Greek Attitudes to Animals, 600-300 BC. Studies in Classical Archaeology V. BAR International Series 2225. Oxford: Archaeopress.

Carstens, Anne Marie. 2005. To Bury a Ruler: The Meaning of the Horse in Aristocratic Burials. In Cyprus: Religion and Society from the Late Bronze Age to the End of the Archaic Period. Proceedings of an International Symposium on Cypriote Archaeology, Erlangen, 23-24 July 2004. Edited by Vassos Karageorghis, Hartmut Matthäus and Sabine Rogge. Möhnesee-Wamel: Bibliopolis, pp. 57-76.

Chapman, John C. 2000a. Fragmentation in Archaeology: People, Places and Broken Objects in the Prehistory of South-Eastern Europe. London and New York: Routledge.

Chapman, John C. 2000b. Tension at funerals: Social practices and the subversion of community structure in later Hungarian prehistory. In Agency in Archaeology. Edited by Marcia-Anne Dobres and John E. Robb. London and New York: Routledge, pp. 169-95.

Chapman, John C., and Bisserka Gaydarska. 2007. Parts and Wholes: Fragmentation in Prehistoric Context. Oxford: Oxbow.

Choyke, Alice M. 2010. The Bone is the Beast: Animal Amulets and Ornaments in Power and Magic. In Anthropological Approaches to Zooarchaeology: Complexity, Colonialism, and Animal Transformations. Edited by Douglas V. Campana, Pamela Crabtree, Susan D. de France, Justin Lev-Tov and Alice M. Choyke. Oxford: Oxbow Books, pp. 197-209.

Clutton-Brock, Juliet. 1981. Domesticated Animals from Early Times. Austin: University of Texas Press.

Dandoy, Jeremiah R. 2006. Astragali through Time. In Integrating Zooarchaeology. Proceedings of the 9th ICAZ Conference, Durham 2002. Edited by Mark Maltby. Oxford: Oxbow, pp. 131-37.

De Grossi Mazzorin, Jacopo, and Claudia Minniti. 2013. Ancient use of the knuckle-bone for rituals and gaming piece. Anthropozoologica 48: 371-80. [CrossRef]

Draksler, Matej. 2007. Območje Zagorja ob Savi v prazgodovini/Das Gebiet von Zagorje ob Savi in der Vorgeschichte. Arheološki vestnik 58: 121-55.

Dular, Janez. 2003. Halštatske Nekropole Dolenjske/Die Hallstattzeitlichen Nekropolen in Dolenjsko. Opera Instituti Archaeologici Sloveniae 6. Ljubljana: Zalžoba ZRC.

Dular, Janez. 2007. Pferdegräber und Pferdebestattungen in der hallstattzeitlichen Dolenjsko-Gruppe. In Scripta Praehistorica in Honorem Biba Teržan. Edited by Martina Blečić, Matija Črešnar, Bernhard Hänsel, Anja Hellmuth, Elke Kaiser and Carola Metzner-Nebelsick. Ljubljana: Narodni muzej Slovenije, Situla 44. pp. 737-52.

Dular, Janez, and Borut Križ. 1990. Železnodobno naselje in grobišče v Brezjah pri Trebelnem/Die eisenzeitliche Siedlung und Nekropole in Brezje bei Trebelno. Arheološki vestnik 41: 531-56.

Dular, Janez, and Sneža Tecco Hvala. 2007. South-Eastern Slovenia in the Early Iron Age: Settlement_Economy-Society/ Jugovzhodna Slovenija v Starejši Železni dobi: Poselitev, Gospodarstvo, Družba. Opera Instituti Archaeologici Sloveniae 12. Ljubljana: Založba ZRC.

Eibner, Alexandrine. 1981. Darstellungsinhalte in der Kunst der Hallstattkultur: Gedanken zum "überhöhten" Leben im Situlenbereich und Osthallstattkreis. In Die Hallstattkultur. Bericht über das Symposium in Steyr 1980 aus Anlaß der Internationalen Ausstellung des Landes Oberösterreich. Edited by Clemens Eibner. Linz: Kommission Beim Oo. Landesverlag, pp. 261-96.

Ekroth, Gunnel. 2014. Animal Sacrifice in Antiquity. In The Oxford Handbook of Animals in Classical Thought and Life. Edited by Gordon Lindsay Campbell. Oxford: Oxford University Press, pp. 324-54.

Fahlander, Fredrik, and Terje Oestigaard. 2008. The Materiality of Death: Bodies, Burials, Beliefs. In The Materiality of Death: Bodies, Burials, Beliefs. Edited by Fredrik Fahlander and Terje Oestigaard. Oxford: Archaeopress, pp. 1-16.

Fowler, Murray E. 1995. Restraint and Handling of Wild and Domestic Animals. Ames: Iowa State University Press. 
Frey, Otto Hermann. 1991. "Celtic Princes" in the Sixth Century B.C. In The Celts. Edited by Sabatino Moscati, Otto Hermann Frey, Venceslas Kruta, Barry Raftery and Miklós Szabó. New York: Rizzoli, pp. 74-92.

Frey, Otto-Herman. 2011. The World of Situla Art. In The Barbarians of Ancient Europe: Realities and Interactions. Edited by Larissa Bonfante. Cambridge: Cambridge University Press, pp. 282-312.

Frie, Adrienne C. 2016. Assembling animals: Actual, figural, and imagined. In Incomplete Archaeologies: Assembling Knowledge in the Past and Present. Edited by Emily Miller Bonney, Kathryn J. Franklin and James A. Johnson. Oxford: Oxbow Books, pp. 64-83.

Frie, Adrienne C. 2017. Cultural Constructions of Nature: Animal Representation and Use in Early Iron Age Southeastern Slovenia. Ph.D. dissertation, University of Wisconsin-Milwaukee, Milwaukee, WI, USA.

Frie, Adrienne C. 2018a. Horses and the embodiment of elite masculinity in the Dolenjska Hallstatt culture. Oxford Journal of Archaeology 37: 25-44. [CrossRef]

Frie, Adrienne C. 2018b. Insignia of power: Bird imagery on artefacts of hierarchy and ritual in Iron Age Dolenjska (SE Slovenia). Documenta Praehistorica XLV: 166-78. [CrossRef]

Frie, Adrienne C. 2019. Extraordinary Creatures: The Role of Birds in Early Iron Age Slovenia. Environmental Archaeology 24: 400-10. [CrossRef]

Gabrovec, Stane. 1966. Zur Halstattzeit in Slowenien. Germania 44: 1-48.

Gabrovec, Stane. 1976. Zum Beginn der Hallstattzeit in Slowenien. In Festschrift für Richard Pittoni zum siebzigsten Geburtstag. Edited by Herbert Mitscha-Märheim, Herwig Friesinger and Helga Kerchler. Wien and Horn: Franz Deuticke \& Ferdinand Berger und Söhne OHG, pp. 588-600.

Gabrovec, Stane. 1999. 50 Jahre Archäologie der älteren Eisenzeit in Slowenien/50 let arheologije starejše železne dobe v Sloveniji. Arheološki vestnik 50: 145-88.

Gabrovec, Stane, ed. 2006. Stična II/1. Gomile Starejše Železne dobe/Grabhügel aus der Aelteren Eisenzeit. Katalogi in Monografije 37. Ljubljana: Narodni muzej Slovenije.

Gabrovec, Stane, and Ana Kruh. 2006a. Gomila 5/Grabhügel 5. In Stična II/1. Gomile Stareǰ̌e Železne dobe/Grabhügel aus der Aelteren Eisenzeit. Edited by Stane Gabrovec. Katalogi in Monografije 37. Ljubljana: Narodni muzej Slovenije, pp. 130-53.

Gabrovec, Stane, and Ana Kruh. 2006b. Gomila 48/Gräbhugel 48. In Stična II/1. Gomile Starejše Železne Dobe/Grabhügel aus der Aelteren Eisenzeit. Edited by Stane Gabrovec. Katalogi in Monografije 37. Ljubljana: Narodni muzej Slovenije, pp. 14-129.

Gabrovec, Stane, and Biba Teržan, eds. 2010. Stična II/2. Gomile starejše železne dobe. Razprave/Grabhügel aus der alteren Eisenzeit. Studien. Katalogi in Monografije 38. Ljubljana: Narodni Muzej Slovenije. First published 2008.

Game, Ann. 2001. Riding: Embodying the Centaur. Body and Society 7: 1-12. [CrossRef]

Gruškovnjak, Luka. 2016. Grobovi z živalskimi kostmi v času starejše železne dobe v Sloveniji. Master's dissertation, University of Ljubljana, Ljubljana, Slovenia.

Guštin, Mitja. 1976. Libna. Posavski muzej Brežice Knjiga 3. Brežice: Posavski muzej Brežice.

Guštin, Mitja, and Biba Teržan. 1975. Malenškova gomila v Novem mestu: Prispevek k ponavanju povezav med jugozhodnim alpskim svetom, severozahodnim Balkanom in južno Panonijo v starejši želeni dobi. Arheološki vestnik 26: 188-202.

Hamilakis, Yannis, and Eleni Konsolaki. 2004. Pigs for the Gods: Burnt Animal Sacrifices as Embodied Rituals at a Mycenaean Sanctuary. Oxford Journal of Archaeology 23: 135-51. [CrossRef]

Hamilakis, Yannis, and Nick J. Overton. 2013. A Multi-Species Archaeology. Archaeological Dialogues 20: $159-73$. [CrossRef]

Härke, Heinrich. 2014. Grave goods in early medieval burials: Messages and meanings. Mortality 19: 41-60. [CrossRef]

Hencken, Hugh. 1978. The Iron Age Cemetery of Magdalenska Gora in Slovenia. Mecklenburg Collection Papers, Bulletin 32. Cambridge: Harvard University Press, American School of Prehistoric Research.

Horard-Herbin, Marie-Pierre, Anne Tresset, and Jean-Denis Vigne. 2014. Domestication and uses of the dog in western Europe from the Paleolithic to the Iron Age. Animal Frontiers 4: 23-31. [CrossRef]

Insoll, Timothy. 2010. Talensi animal sacrifice and its archaeological implications. World Archaeology 42: 231-44. [CrossRef] 
Kimmig, Wolfgang. 1991. The Heuneburg Hillfort and the Proto-Celtic Princely Tombs of Upper Rhineland. In The Celts. Edited by Sabatino Moscati, Otto Hermann Frey, Venceslas Kruta, Barry Raftery and Miklós Szabó. New York: Rizzoli, pp. 114-15.

Kmet'ová, Petra. 2013a. "Masters of Horses" in the West, "Horse Breeders" in the East? On the Significance and Position of the Horse in the Early Iron Age Communities of the Pannonian Basin. In Interpretierte Eisenzeiten. Fallstudien, Methoden, Theorie. Tagungsbeiträge der 5. Linzer Gespräche zur interpretativen Eisenzeitarchäologie. Edited by Raimund Karl and Jutta Leskovar. Linz: Oberösterreichischen Landesmuseum, pp. 278-58.

Kmet'ová, Petra. 2013b. The Spectacle of the Horse: On Early Iron Age Burial Customs in the Eastern-Alpine Hallstatt Region. Archaeological Review from Cambridge 28: 67-81.

Kmet'ová, Petra. 2018. "And four strong-necked horses he threw swiftly on the pyre ... " On human-horse relationship in the Early Iron Age Central Europe from the perspective of interregional contacts. In EҮ $\triangle A I M \Omega N$. Studies in Honour of Jan Bouzek. Edited by Peter Pavúk, Věra Klontza-Jaklová and Anthony Harding. Prague: Faculty of Arts, Charles University, Opera Facultatis Philosophicae Universitatis Carolinae Pragensis, vol. XVIII, pp. 267-89.

Kmet'ová, Petra, and Susanne Stegmann-Rajtár. 2014. Zur symbolischen Bestattung von Pferdeschädeln in Gräbern der späten Urnenfelder- und älteren Hallstattzeit/K simboliki konjskih lobanj v grobovih iz poznega žarnogrobiščnega in starejšega halštatskega obdobja (Povzetek). In Studia Praehistorica in Honorem Janez Dular. Edited by Sneža Tecco Hvala. Opera Instituti Archaeologici Sloveniae 30. Ljubljana: Založba ZRC, pp. 149-66.

Knez, Tone. 1993. Novo mesto III. Kapiteljska Njiva. Knežja Gomila/Novo mesto III. Kapiteljska Njiva. Fürstengrabhügel. Carniola archaeologica 3. Novo mesto: Dolenjski muzej.

Knez, Tone, and Stanko Škaler. 1968. Halštatska gomila na Libni/Der Hallstatt-Grabhügel auf der Libna. Arheološki vestnik XIX: 239-72.

Kossack, Georg. 1998. Horse and Wagon during the Early Iron Age in Central Europe. Technical Considerations, Nature of Evidence and Conceptual Content. In Towards Translating the Past. Georg Kossack-Selected Studies in Archaeology. Ten Essays from the Year 1974 to 1997. Edited by Bernhard Hänsel and Anthony F. Harding. Rahden: Verlag Marie Leidorf GmbH, pp. 97-106.

Krausse, Dirk. 2007. The "Celtic Prince" of Hochdorf: Village-Elder or Sacred King? Pretense and Reality of the So-Called "Cultural Anthropological" Hallstatt Archaeology. In The Celtic World: Critical Concepts in Historical Studies. Edited by Raimund Karl and David Stifter. London and New York: Routledge, pp. 197-229.

Križ, Borut. 1997. Kapiteljska njiva: Novo mesto. Katalog Arheološke Razstave. Novo mesto: Dolenjski muzej.

Križ, Borut. 2012. Odsevi Prazgodovine v bronu: Situlska umetnost Novega mesta/Reflections of Prehistory in Bronze: The Situla Art of Novo mesto. Novo mesto: Dolenjski muzej.

Križ, Borut, Mojca Jereb, and Biba Teržan. 2014. Kapiteljska njiva. In Absolutno Datiranje Bronaste in železne dobe na Slovenskem/Absolute Dating of the Bronze and Iron Ages in Slovenia. Edited by Biba Teržan and Matija Črešnar. Katalogi in Monografije 40. Ljubljana: Univerza v Ljubljani \& Narodni muzej Slovenije, pp. 473-84.

Kromer, Karl. 1959. Brezje: Halštatske Gomile z Brezij pri Trebelnem/Hallstättische Hügelgräber aus Brezje bei Trebelno. Arheološki katalogi Slovenije 2. Ljubljana: Narodni muzej Slovenije.

Kromer, Karl. 1980. Das Situlenfest: Versuch einer Interpretation der Darstellungen auf figural verzierten Situlen. In Zbornik Posvečen Stanetu Gabrovcu ob Šestdesetletnici. Edited by Peter Petru. Ljubljana: Narodni muzej Slovenije, pp. 225-40.

Kuzmina, Elena E. 2006. Mythological Treatment of the Horse in Indo-European Culture. In Horses and Humans: The Evolution of Human-Equine Relationships. Edited by Sandra L. Olsen, Susan Grant, Alice M. Choyke and László Bartosiewicz. Oxford: Archaeopress, pp. 263-70.

Laharnar, Boštjan, and Peter Turk. 2018. Iron Age Stories from the Crossroads. Ljubljana: Narodni muzej Slovenije. Leghissa, Elena. 2015. Način okraševanja keramike ljubljanske kulture in pramenaste keramike-Eksperimentalna arheologija/Decorating the pottery of the Ljubljana culture and the Litzen pottery-An experimental archaeology case study. Arheološki vestnik 66: 275-92.

Lücke, Judith. 2007. Das Lappenbeil im mittleren Alpenraum als Motiv in bildlichen und plastischen Darstellungen. In Scripta Praehistorica in Honorem Biba Teržan. Edited by Martina Blečić, Matija Črešnar, Bernhard Hänsel, Anja Hellmuth, Elke Kaiser and Carola Metzner-Nebelsick. Ljubljana: Narodni muzej Slovenije, Situla 44. pp. 597-601. 
Lucke, Wolfgang, and Otto-Herman Frey. 1962. Die Situla in Providence (Rhode Island). Ein Beitrag zur Situlenkunst des Osthallstattkreises. Römisch-germanische Forschungen 26. Berlin: de Gruyter.

Mlekuž, Dimitrij. 2013. The Birth of the Herd. Society \& Animals 21: 150-61. [CrossRef]

Morey, Darcy F. 2006. Burying key evidence: The social bond between dogs and people. Journal of Archaeological Science 33: 158-75. [CrossRef]

Morris, James. 2008. Associated bone groups; one archaeologist's rubbish is another's ritual deposition. In Changing Perspectives on the First Millennium BC. Edited by Oliver Davis, K. Waddington and Niall Sharples. Oxford: Oxbow, pp. 83-98.

Morris, James. 2011. Investigating Animal Burials: Ritual, Mundane and Beyond. BAR British Series 535. Oxford: Archaeopress.

Morris, James. 2012. Animal "Ritual” Killing: From Remains to Meanings. In The Ritual Killing and Burial of Animals: European Perspectives. Edited by Aleksander Pluskowski. Oxford: Oxbow Books, pp. 8-21.

Nilsson Stutz, Liv, and Sarah Tarlow. 2013. Beautiful Things and Bones of Desire. In The Oxford Handbook of the Archaeology of Death and Burial. Edited by Liv Nilsson Stutz and Sarah Tarlow. Oxford: Oxford University Press, pp. 1-14.

Parker Pearson, Mike. 1999. The Archaeology of Death and Burial. Texas College Station: A\&M University Press.

Pauli, Ludwig. 1975. Keltischer Volksglaube: Amulette und Sonderbestattungen am Dürrnberg bei Hallein und im Eisenzeitlichen Mitteleuropa. München: C. H. Beck.

Pilaar Birch, Suzanne E. 2018. Introduction. In Multispecies Archaeology. Edited by Suzanne E. Pilaar Birch. London: Routledge, pp. 1-7.

Pluskowski, Aleksander. 2012. The Ritual Killing and Burial of Animals. In The Ritual Killing and Burial of Animals: European Perspectives. Edited by Aleksander Pluskowski. Oxford: Oxbow, pp. 1-7.

Puš, Ivan. 1971. Žarnogrobiščna Nekropola na Dvorišču SAZU v Ljubljani: Izkopavanja v letih 1964-1956/Nekropole der Urnenfelderkultur im Hof der Slowenischen Akademie der Wissenschaften und Künste in Ljubljana: Ausgrabungen in den jahren 1964-1965. Razprave/Dissertationes VII/1. Ljubljana: Slovenska Akademija Znanosti in Umetnosti.

Puš, Ivan. 1982. Prazgodovinsko žarno Grobišče v Ljubljani/Das Vorgeschichtliche Urnengräberfeld in Ljubljana. Razprave/Dissertationes XIII/2. Ljubljana: Slovenska Akademija Znanosti in Umetnosti.

Rask, Katie A. 2014. Etruscan Animal Bones and Their Implications for Sacrificial Studies. History of Religions 53: 269-312. [CrossRef]

Škvor Jernejčič, Brina. 2014. Žarna nekropola v Ljubljani in preobrazba Ljubljanske skupine na prehodu iz bronaste v železno dobo. Ph.D. dissertation, Univerza v Ljubljani, Ljubljana, Slovenia.

Škvor Jernejčič, Brina. 2017. Graves from the Early Hallstatt Period at Molnik. In Molnik pri Ljubljani v Železni dobi/The Iron Age Site at Molnik near Ljubljana. Edited by Sneža Tecco Hvala. Opera Instituti archaeologici Sloveniae 36. Ljubljana: Založba ZRC, pp. 140-53.

Škvor Jernejčič, Brina, and Borut Toškan. 2018. Ritual use of dogs and wolves in the Late Bronze and Early Iron Age in the South-Eastern Alpine region. New evidence from the archaeo(zoo)logical perspective. In Animal Symbolisé, Animal Exploité: Du Paléolithique à la Protohistoire. Edited by Sandrine Costamagno, Lionel Gourichon, Catherine Dupont, Olivier Dutour and Denis Vialou. Paris: Éditions du Comité des travaux historiques et scientifiques, pp. 249-78.

Starè, France. 1955. Vače. Arheološki Katalogi Slovenije 1. Ljubljana: Narodni Muzej Slovenije.

Stipančić, Petra. 2016a. Dolenjski muzej, Novo mesto, Slovenia. Personal communication.

Stipančić, Petra. 2016b. Podoba ali Simbol: Upodobitve živali na Arheoloških Predmetih. Katalog Razstave, 14. Oktober 2016-14. januar 2017/Image or Symbol: Depictions of Animals on Archaeological Artefacts. Exhibition Catalogue, 14th October 2016-14th January 2017. Novo mesto: Dolenjski muzej.

Tarlow, Sarah. 1999. Bereavement and Commemoration: An Archaeology of Mortality. Oxford: Blackwell.

Tecco Hvala, Sneža. 2012. Magdalenska gora: Družbena Struktura in Grobni Rituali Železnodobne Skupnosti/Magdalenska gora: Social Structure and Burial Rites of the Iron Age Community. Opera Instituti Archaeologici Sloveniae 26. Ljubljana: Založba ZRC.

Tecco Hvala, Sneža, Janez Dular, and Eva Kocuvan. 2004. Železnodobne gomile na Magdalenski gori/Eisenzeitliche Grabhügel auf der Magdalenska gora. Katalogi in Monografije 36. Ljubljana: Narodni muzej Slovenije.

Teržan, Biba. 2011. Horses and Cauldrons: Some Remarks on Horse and Chariot Races in Situla Art. Notizie Archeologiche Bergomensi 19: 303-25. 
Teržan, Biba. 2012. Sfinga v situlski umetnosti ob severnem Jadranu in njegovem zaledju/The sphinx in Situla Art in the northern Adriatic region and its hinterland. In Scripta in Honorem Bojan Djurić. Edited by Branka Migotti, Phil Mason, Barbara Nadbath and Tadeja Mulh. Ljubljana: Zavod za varstvo kulturne dediščine Slovenije, pp. 170-96.

Teržan, Biba. 2014. Prvi med prvimi-O centralnem grobu gomile I na Kapiteljski njivi v Novem mestu/First among firsts-The central grave of tumulus I at the Kapiteljska njiva in Novo mesto. In Studia Praehistorica in Honorem Janez Dular. Edited by Sneža Tecco Hvala. Opera Instituti Archaeologici Sloveniae 30. Ljubljana: Založba ZRC, pp. 251-83.

Teržan, Biba. Forthcoming. Vače. Katalogi in monografije. Ljubljana: Narodni muzej Slovenije, in preparation.

Theodossopoulos, Dimitrios. 2005. Care, Order and Usefulness: The Context of Human-Animal Relationship in a Greek Island Community. In Animals in Person: Cultural Perspectives on Human-Animal Intimacy. Edited by John Knight. Oxford: Berg, pp. 15-35.

Toškan, Borut. 2017a. Burnt horse remains in Grave 6, Tumulus 17, from Grmada at Molnik. In Molnik pri Ljubljani v Železni dobi/The Iron Age Site at Molnik near Ljubljana. Edited by Sneža Tecco Hvala. Opera Instituti archaeologici Sloveniae 36. Ljubljana: Založba ZRC, pp. 198-209.

Toškan, Borut. 2017b. Institute of Archaeology at the Research Centre of the Slovenian Academy of Sciences and Arts, Ljubljana, Slovenia. Personal communication.

Turk, Peter. 2005. Images of Life and Myth. Ljubljana: Narodni muzej Slovenije.

Valera, António Carlos, and Cláudia Costa. 2013. Animal limbs in funerary contexts in southern Portugal and the question of segmentation. Anthropozoologica 48: 263-75. [CrossRef]

Watts, Christopher, ed. 2013. Relational Archaeologies: Humans, Animals, Things. London: Routledge.

Wells, Peter S. 1981. The Emergence of an Iron Age Economy: The Mecklenburg Grave Groups from Hallstatt and Stična. Mecklenburg Collection, Part III. Cambridge: The Peabody Museum of Archaeology and Ethnology, Harvard University, American School of Prehistoric Research Bulletin 33.

Wiesner, Norbert. 2013. Astragali in Gräbern der mitteleuropäischen Urnenfelderkultur. Germania 91: 89-113.

Williams, Howard. 2004. Death Warmed up: The Agency of Bodies and Bones in Early Anglo-Saxon Cremation Rites. Journal of Material Culture 9: 263-91. [CrossRef]

(C) 2020 by the author. Licensee MDPI, Basel, Switzerland. This article is an open access article distributed under the terms and conditions of the Creative Commons Attribution (CC BY) license (http://creativecommons.org/licenses/by/4.0/). 